\title{
2. SONOBUOY SEISMIC STUDIES AT ODP DRILL SITES IN PRYDZ BAY, ANTARCTICA ${ }^{1}$
}

\author{
Guy R. Cochrane ${ }^{2}$ and Alan K. Cooper ${ }^{2}$
}

\begin{abstract}
Five sonobuoy seismic-refraction records were collected along the Leg 119 geophysical transect across the Prydz Bay shelf. Velocity-depth profiles are computed from the sonobuoy data and are used to produce a depth section for the principal acoustic unit boundaries observed in the seismic-reflection data along the transect. Traveltime curves generated by ray-tracing for models constructed from downhole velocity logs are compared to curves generated for models based solely on the sonobuoy data. This comparison reveals that sonobuoy data are less reliable for analysis of lithostratigraphy in vertically and laterally complex areas; however, the sonobuoy data can be used to accurately estimate the depth to a specific horizon in the reflection data to within $10 \mathrm{~m}$. Near-surface velocities exceed $2.0 \mathrm{~km} / \mathrm{s}$ at all sites, indicating likely overconsolidation of sediments due to glacial loading and erosion during periods of grounded ice sheets on the shelf. Sedimentary rock velocities exclusively were observed beneath the shelf to depths of $3 \mathrm{~km}$. At the landward site a deep refraction is observed with a velocity and vertical gradient indicative of basement rock.
\end{abstract}

\section{INTRODUCTION}

On Ocean Drilling Program (ODP) Leg 119 several geophysical survey lines were run to complete a transect of the continental shelf of the Prydz Bay region (Fig. 1). Five sonobuoy-seismic records were collected in addition to seismic-reflection and magnetic data (Cooper et al., this volume). Most of the buoys were deployed near the planned drill sites during shooting of short seismic-reflection lines perpendicular to the drilling transect. The drilling transect structural profile shown in Cooper et al.'s figure 2 is based on an interpretation of pieces of Leg 119 seismic reflection profiles 4 to 8 .

Prior to Leg 119 only limited seismic-refraction data had been obtained on the Prydz Bay continental shelf by Japan (Mizukoshi et al., 1988) and the USSR (G. Grikorov, pers. comm., 1989). Studies elsewhere around Antarctica suggest that overconsolidation of near-surface sediments results from glacial loading (Haugland et al., 1985; Davey et al., 1983; Childs and Stagg, 1987; Cooper et al., 1987; Solheim et al., chapter 9, this volume). In this study we calculate vertical velocity profiles and we correlate areally extensive high-velocity layers with layers that have been glacially loaded, as determined by geotechnical analysis of drilling samples.

The sonobuoy data are also used to map the local and regional velocity variations in Prydz Bay, we use the data to distinguish the contacts between acoustic units, and to estimate the thickness of the rock units at each sonobuoy site. The acoustic units, described in the following, are a slight modification of the units defined by Stagg (1985).

In this study we also examine the usefulness of sonobuoy data in detailed vertical velocity analysis. Both sonobuoy and downhole logging velocities (Barron, Larsen, et al., 1989) were recorded at Sites 739 and $\mathbf{7 4 2}$. For these two sites we constructed velocity-depth models based on the downhole logging data and generated refraction and wide-angle reflection traveltime curves for comparison to the sonobuoy seismic records. The comparisons reveals the limitations of the slope-intercept, $x^{2}$ vs. $t^{2}$, and ray-tracing methods of interpreting sonobuoy seismic data in

\footnotetext{
${ }^{1}$ Barron, J., Larsen, B., et al., 1991. Proc. ODP, Sci. Results, 119: College Station, TX (Ocean Drilling Program).

2 U.S. Geological Survey, MS-999, 345 Middlefield Road, Menlo Park, CA 94025 , U.S.A.
}

stratigraphically complex areas. The sonobuoy data can be used to estimate depth to horizons targeted for drilling to within approximately $10 \mathrm{~m}$, but vertical sequences of layers of approximately $10 \mathrm{~m}$ in thickness and velocity inversions could not be predicted accurately with sonobuoy data.

\section{ACOUSTIC ROCK UNITS}

A reinterpretation of Stagg's (1985) acoustic units on the shelf and uppermost slope, where drilling was done, is given in Cooper et al. (this volume). The acoustic units are distinguished on the basis of acoustic character (Cooper et al., this volume) and lithologic sampling (Barron, Larsen, et al., 1989). A brief overview is provided as follows:

\section{Unit PS.1}

Unit PS. 1 is a flat-lying unit, directly below the seafloor. It is characterized by chaotic and incoherent reflections with some strong reflection horizons that can be traced widely across the outer shelf along the drilling transect (Fig. 2). It is composed of diatomaceous clay underlain by thinly bedded to massive diamictite. The unit is marine and of glacial and probably interglacial origins and is as old as late Miocene-early Pliocene. It unconformably overlies deeper units.

\section{Unit PS.2A}

Unit PS.2A is characterized in the seismic-reflection data by semicontinuous, relatively undeformed reflections that thicken and dip gently seaward across the central shelf and abruptly dip more steeply beneath the outer shelf. The rocks of unit PS.2A are primarily upper Eocene to lower Oligocene and younger massive to friable marine-glacial diamictites. At Site $\mathbf{7 4 2}$ deformed sands and carbonaceous shales that are included in unit PS.2A were sampled, beneath the diamictite.

\section{Unit PS.2B}

Unit PS.2B is characterized by discontinuous reflections in inner shelf areas and continuous reflections in the outer shelf areas. Inner shelf rocks were sampled at Site 741 and are Lower Cretaceous(?) nonmarine sandstone and fine-grained silt, relatively rich in carbonized plant material.

\section{Unit PS.3}

Rocks from unit PS.3 were not found along the Leg 119 transect. 


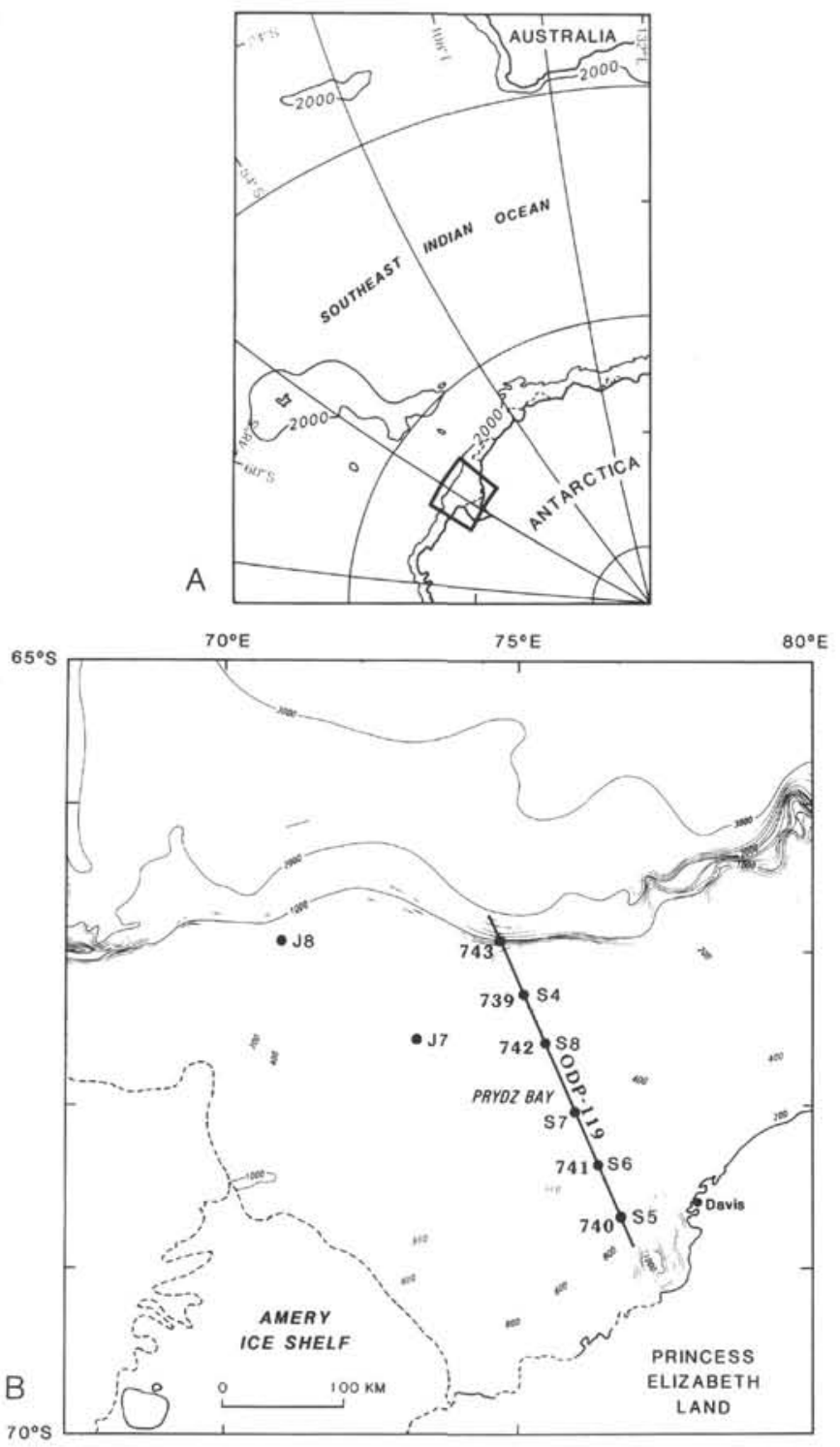

Figure 1. Index maps of Prydz Bay. A. Map of Antarctica and the southern Indian Ocean showing study area. B. Study area bathymetry (in meters) and location of sonobuoy deployment sites (Sonobuoys S4S8, Leg 119; J7-J8, Japanese), and Leg 119 drill Sites 739-743.

\section{Unit PS.4}

Unit PS. 4 is seen beneath the inner shelf as a poorly- to welllayered sequence of low-amplitude reflections that dip seaward. An angular unconformity separates units PS.4 and PS.2B. A non-marine sequence of nonfossiliferous red bed sandstones and siltstones was recovered from the middle of PS. 4 at Site 740 .

\section{Unit PS.5}

Unit PS.5 is an acoustically opaque unit that lies beneath unit PS.4. The top of unit PS.5 is a high-amplitude continuous reflection that is mostly without relief along the transect. The unit was not sampled. It is interpreted on the basis of seismic and magnetic data to be composed of basement rocks of Precambrian age (Cooper et al., this volume).

\section{SEISMIC-REFRACTION DATA}

The sonobuoy system and methods for ODP sonobuoy operations are described in Barron, Larsen, et al. (1989). Initial shipboard interpretation techniques are described by Childs and Cooper (1975). Seismic data are transmitted by the buoy to a UHF receiver aboard ship. The data are band-pass filtered from 5 to $200 \mathrm{~Hz}$, amplified, and recorded on digital tape (1-ms samples) and paper records.

Initial interpretation was done aboard ship from paper records using the $x^{2}$ vs. $t^{2}$ method (Barron, Larsen, et al., 1989). Dip corrections were not applied to these data. The velocities are shown in Table 1 . Some error exists in these velocity estimates due to the difficulty in picking the direct wave arrival times from the analog records. The digital sonobuoy data were subsequently processed and plotted at the U.S. Geological Survey DISCO processing facility in Menlo Park. Spectral analysis of the sonobuoy data indicate that significant seismic energy exists in the data at frequencies as high as $100 \mathrm{~Hz}$. The data were band-pass filtered from 20 to $180 \mathrm{~Hz}$ and amplified with automatic gain control except where noted otherwise.

Wide-angle reflection and refraction traveltime curves were calculated using the ray-tracing method (McMechan and Mooney, 1980), which allows use of two-dimensionally varying velocities and structure. The location of the sonobuoy hydrophone is set at $0 \mathrm{~km}$ distance and $0.02 \mathrm{~km}$ depth. Rays are propagated through the model using the Cervany et al. (1977) algorithm. The traveltime-distance values obtained for rays that reflect off layer boundaries or refract through layers with a vertical gradient are plotted on the sonobuoy data.

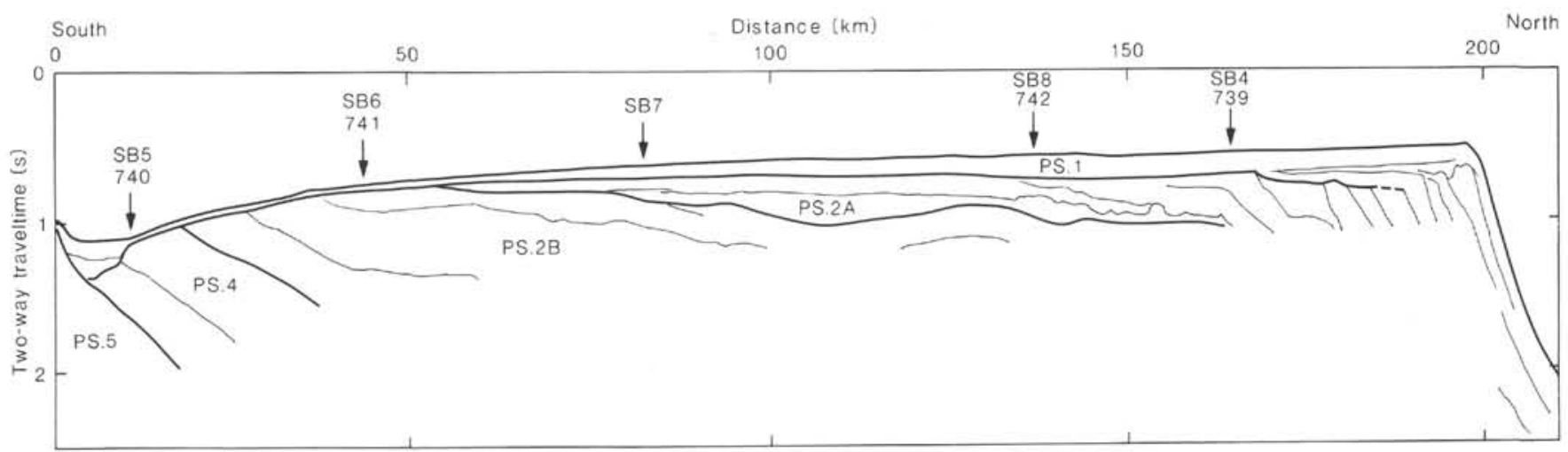

Figure 2. Interpretive line drawing based on seismic reflection data (Barron, Larsen, et al., 1989) across Prydz Bay showing acoustic units from Cooper et al. (this volume). Heavy lines indicate acoustic unit boundaries. See Figure 1 for location. Sonobuoy and drill site locations are shown by arrows. 
Table 1. Seismic refraction solutions based on $x^{2}$ vs. $t^{2}$ and slope-intercept for sonobuoy measurements in Prydz Bay during 1988.

\begin{tabular}{|c|c|c|c|c|c|c|c|c|c|c|c|}
\hline \multirow[b]{2}{*}{ Sonobuoy } & \multirow{2}{*}{$\begin{array}{l}\text { Latitude }\left({ }^{\circ} \mathrm{S}\right) \\
\text { Line } \\
\text { Shotpoint }\end{array}$} & \multirow{2}{*}{$\begin{array}{l}\text { Longitude }\left({ }^{\circ} \mathrm{E}\right) \\
\text { Site }\end{array}$} & \multirow{2}{*}{$\begin{array}{l}\text { Water } \\
\text { depth } \\
\text { (m) }\end{array}$} & \multicolumn{2}{|c|}{ Layer 1} & \multicolumn{2}{|c|}{ Layer 2} & \multicolumn{2}{|c|}{ Layer 3} & \multicolumn{2}{|c|}{ Layer 4} \\
\hline & & & & $V_{0}$ & $h$ & $V_{0}$ & $h$ & $V_{0}$ & $h$ & $V_{0}$ & $h$ \\
\hline 4 & $\begin{array}{l}67.28 \\
4 \\
1403\end{array}$ & $\begin{array}{l}75.05 \\
739\end{array}$ & 412 & 1.83 & 0.12 & 2.33 & 0.19 & 2.61 & 0.31 & 2.41 & 0.14 \\
\hline 5 & $\begin{array}{l}68.70 \\
5 \\
2051\end{array}$ & $\begin{array}{l}76.65 \\
740\end{array}$ & 814 & 2.46 & 0.34 & 3.08 & 0.48 & & & & \\
\hline 6 & $\begin{array}{l}68.37 \\
6 \\
32408\end{array}$ & $\begin{array}{l}76.41 \\
741\end{array}$ & 551 & 2.48 & 0.39 & 2.80 & 0.58 & & & & \\
\hline 7 & $\begin{array}{l}67.95 \\
7 \\
1967\end{array}$ & 75.85 & 476 & 2.36 & 0.91 & 2.86 & 1.21 & & & & \\
\hline 8 & $\begin{array}{l}67.53 \\
8 \\
4312\end{array}$ & $\begin{array}{l}75.43 \\
742\end{array}$ & 416 & 2.22 & 0.25 & 2.26 & 0.15 & 2.94 & 0.26 & 2.88 & 0.10 \\
\hline
\end{tabular}

Note: $V_{0}$ is the observed velocity in $\mathrm{km} / \mathrm{s}$, and $h$ is the layer thickness in $\mathrm{km}$.

Because of the difficulty in picking the direct wave in the data, an iterative ray-tracing procedure was used to estimate the distance scale for the sonobuoy data. This procedure consisted of matching the water bottom reflection arrival times for various assumed range scales using a model with a fixed water depth and water velocity until a fit between the calculated arrival times and the water bottom curve in the sonobuoy data was obtained. The water column velocity used is $1.46 \mathrm{~km} / \mathrm{s}$ based on temperature and salinity measurements made at Prydz Bay drill sites.

Detailed studies contrasting wide-angle reflection and refraction arrival times predicted for layers observed in downhole logs to sonobuoy data at Sites 739 and 742 are discussed in the following section. Regional studies of sonobuoy models for the Prydz Bay transect are then discussed.

\section{DETAILED VELOCITY-DEPTH STUDY}

Downhole seismic velocity logs were obtained at Sites 739 and 742 (Barron, Larsen, et al., 1989). Sonobuoy seismicrefraction lines were shot over these areas within $1 \mathrm{~km}$ of the drill site (Figs. 1 and 2), providing us with an opportunity to "ground truth" the sonobuoys. Detailed two-dimensional velocity models to be used for ray-trace modeling were constructed based on the downhole logs.

\section{Sonobuoy 8 (Site 742)}

Site 742 is located $60 \mathrm{~km}$ from the shelf break approximately midway along the Prydz Bay drilling transect. Sonobuoy 8 was deployed in an area of relatively undeformed strata (Fig. 3). Downhole logging results were obtained from 30.8 to 283.8 meters below seafloor (mbsf). The downhole logs showed several large velocity and density variations that can be correlated to unconformities and overcompacted layers (Barron, Larsen, et al., 1989). Two acoustic units were sampled (Cooper et al., this volume).

Unit PS.1 (0.6-0.75 s, 0-175 mbsf; Figs. 3 and 4) is nearly flat and contains high-amplitude reflections that are attributed to glacially compacted (relatively high velocity) and normally consolidated (relatively low velocity) layers.

Unit PS.2A is characterized by weak continuous reflections interpreted to be indicative of normally compacted sediments. These are underlain by sediments that produce high-amplitude, laterally discontinuous reflections of complex shape that are interpreted as unlithified sand bodies of glacial origin.

For ray-trace modeling of sonobuoy 8 , the Site 742 downhole velocities were approximated by numerous discrete layers with linear velocity gradients to derive a velocity-depth function (Figs. 4B and 5B). Layers in the geologic model are flat as in the seismic data (Fig. 3). Figure 5A shows the traveltime-distance curves for rays reflecting off selected layer boundaries and rays refracting through the surface layer. Computed arrivals for rays reflecting off layer boundaries were superimposed on the sonobuoy data (Fig. 5A). In general, the zero-offset two-way traveltimes and curvature do not match between the calculated and observed data. The water bottom reflection curvature does not match between the distances 0.2 and $0.8 \mathrm{~km}$. A range scale for plotting the data was selected such that the calculated water bottom reflection approaches the observed reflection asymptotically with increasing distance. A likely cause for the misfit is local variation in deep water velocity (a value greater than 1.46 $\mathrm{km} / \mathrm{s}$ in this case), or a decrease in the ship's speed or a change in course at approximately $1 \mathrm{~km}$ down range. Normally, when modeling sonobuoy data, a misfit of this magnitude would be corrected by modifying the model before modeling of deeper layers progressed. In this case we will present a second model and discuss the differences between the models.

The sonobuoy data show a high-amplitude first arrival surface (or near-surface) refraction at distances exceeding $1 \mathrm{~km}$ (Figure $5 \mathrm{~A})$. The refraction is caused by high velocities $(2.18$ $\mathrm{km} / \mathrm{sec}$, Table 2) within the upper $30 \mathrm{~m}$, where downhole logs were not recorded. This high velocity in the uppermost section suggests overcompaction of sediment, possibly due to glacial loading (Solheim et al., chapter 9, this volume).

Several interfaces at which large velocity contrasts were observed in the downhole logs are believed to be principally responsible for high-amplitude reflections in the sonobuoy data (RA to RE; Fig. 5). RA was selected as a reflection to be modeled within the upper $100 \mathrm{~m}$ of the section. There are several thin high- and low-velocity zones in the shallower section of the $\log$ (Fig. 4). However, it is not clear that these velocity spikes are actually due to rock physical properties (Barron, Larsen, et al., 1989). The top of a prominent high-velocity layer at a depth of $0.57 \mathrm{~km}$ near the bottom of unit PS. 1 was modeled. The remaining reflections appear to be off boundaries within unit PS.2A (RC to RE; Fig. 5). Reflector RC is the top of a single high-velocity layer. Reflector RD is the first of several reflections off thin layers beneath a significant velocity reversal.

Because of the lack of fit between the synthetic traveltime curves calculated from models based on the downhole log velocities and the sonobuoy data, a second model was constructed using the top-down method in which a fit between the synthetic and the observed data is obtained for each reflection and refrac- 
Distance from sonobuoy $8(\mathrm{~km})$

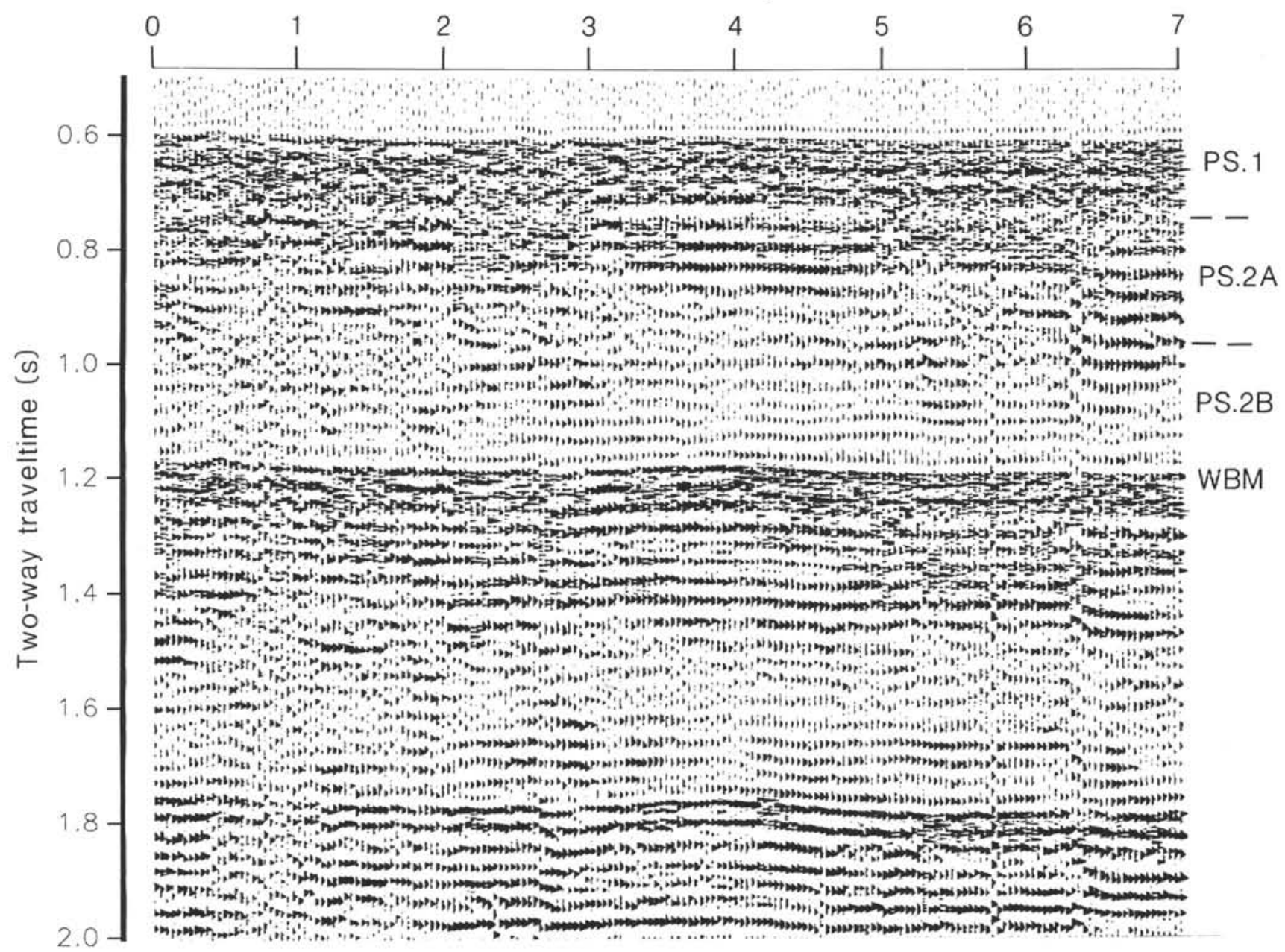

Figure 3. Seismic-reflection profile along strike near Site 742 recorded during shooting of sonobuoy seismic-refraction profile 8 . Location of line shown in Barron, Larsen, et al., 1989. Acoustic units PS.1, PS.2A, and PS.2B are shown at right. WBM = water bottom multiple.

tion before a deeper layer is added to the model (Fig. 6). A slight positive gradient is used in the water column to obtain a better fit for the water bottom reflection. The change in water column velocity necessitated a slight change in the water bottom depth and the range scale. The two-way zero-range traveltimes and the curvature for the synthetic data fit the sonobuoy data significantly better in the second model.

The variation in velocity between the ray-trace model and a smoothed downhole velocity log profile is as much as $0.5 \mathrm{~km} / \mathrm{s}$ where there is a large velocity reversal in the downhole log data $(0.23 \mathrm{~km}$ depth; Fig. 7). Near-surface velocities are higher than normal for sedimentary rock but are lower than the assumed velocities used in the upper section of the downhole log model. The vertically averaged velocity for both the $x^{2}$ vs. $t^{2}$ and raytracing profiles and the downhole log data is approximately 2.3 $\mathrm{km} / \mathrm{s}$. No velocity inversions were required in the ray-trace model to achieve a fit with the exception of reflection RE, the deepest reflection modeled.

The lack of fit between the sonobuoy data and the synthetic data obtained from the model based on the downhole velocity log data may be partly due to variation in the sedimentary sequence between the drilling site and the sonobuoy site or variations in the sequence along the sonobuoy line itself (distances on the order of $1.0 \mathrm{~km}$ ). The comparison of the synthetic data from the downhole log model and the top down model indicates that in areas of complex stratigraphy with thin layers (on the order of $0.01 \mathrm{~km}$ ) and significant velocity variations (on the order of $0.1 \mathrm{~km} / \mathrm{s}$ ) the velocity profile calculated using ray-tracing (or slope intercept methods) can be used as a general velocity curve for prediction of depths to drilling horizons and for conversion of time sections to depth, but cannot be used to accurately determine the velocity for layers $0.01 \mathrm{~km}$ thick.

\section{Sonobuoy 4 (Site 739)}

Sonobuoy 4 was deployed over Site 739 , about $30 \mathrm{~km}$ from the shelf edge (Figs. 1 and 2). Unit PS.1 ( 0.6 to 0.7 s, Fig. $8 ; 170$ mbsf, Fig. 9A), the glacially compacted diamicton, is represented in the seismic-reflection data by the same chaotic and incoherent reflection patterns as observed at Site 742. Likewise, unit PS.2A near both sites has high-amplitude semicontinuous reflections, which dip to the northwest along the transect line (Fig. 2).

A discrete layer velocity-depth function (Fig. 9B) approximating the downhole velocity log was used to construct the raytrace model (Fig. 10B). The near-surface refraction (R1) can be modeled by a layer with a velocity of $2.0 \mathrm{~km} / \mathrm{sec}$ (Table 2). The high-velocity layer at the base of unit PS.1 is approximately 10 $\mathrm{m}$ deeper beneath sonobuoy 4 than at the drill site. In contrast 


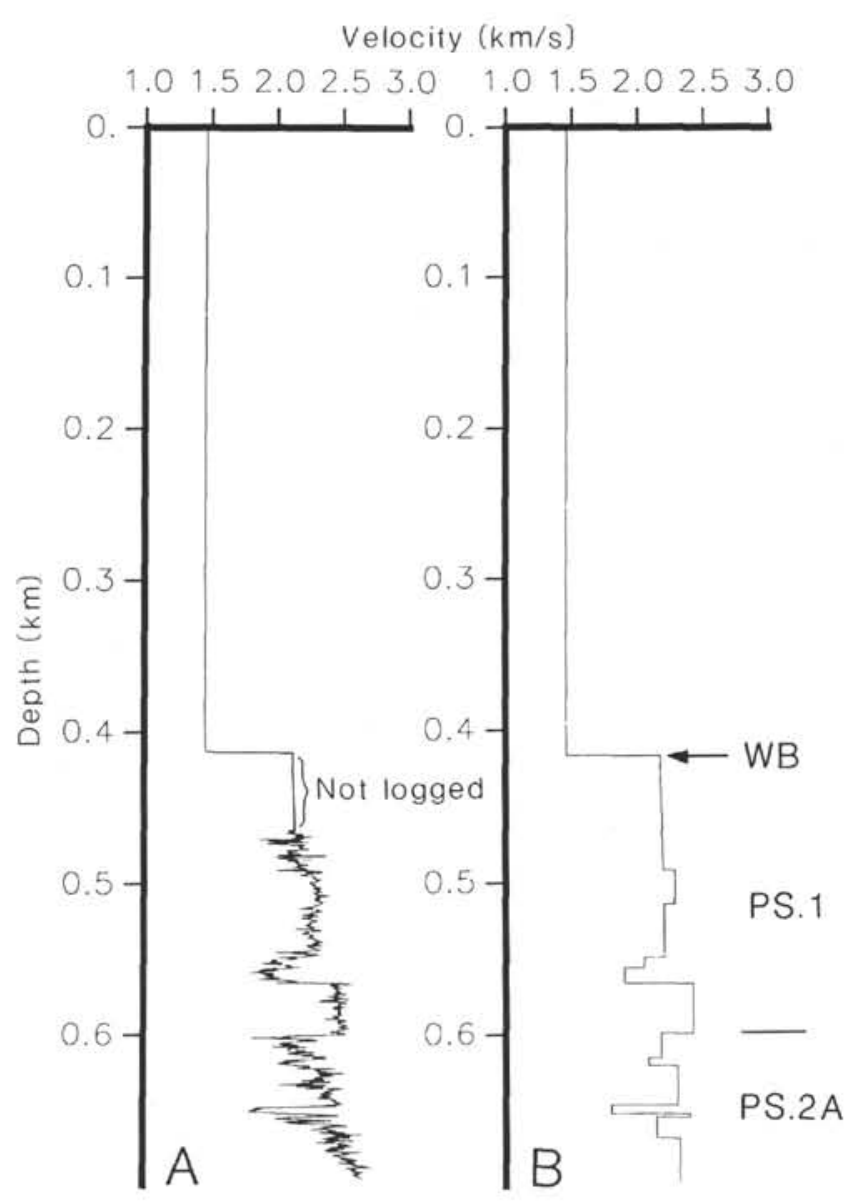

Figure 4. Site 742 velocity-depth profiles. A. Downhole velocity log from Site 742. B. Discrete layer model of downhole log for ray-trace modeling of sonobuoy 8 . WB $=$ water bottom.

to the modeling of Site $\mathbf{7 4 2}$, for Site 739 we altered the velocitydepth function, based on the downhole log, by thickening the top layer of unit PS.1 while maintaining the depth to the contact with unit PS.2A $(0.55 \mathrm{~km}$; Fig. 10B), thereby decreasing the thickness of the high-velocity section within unit PS.1. This slight modification provided a good fit for the vertical-incidence arrival times and for the reflection curvature for reflection RB (Fig. 10A). The deeper synthetic reflections off layer boundaries with high velocity contrast match the observed data well with no additional modification of the velocity-depth model.

\section{Summary of Detailed Velocity Study}

Two seismic events have been roughly correlated between Sites 742 and 739, the near-surface refraction (R1) and the reflection (RB) off the top of the high velocity layer at the base of unit PS.1. Lithologic sampling at Sites 739 and 742 suggest that both events can be attributed to layers of massive diamictite (Barron, Larsen, et al., 1989). The high velocities observed (Table 2) are consistent with glacially overconsolidated sediments, as described by Solheim et al. (chapter 9, this volume).

Ray-trace modeling of sonobuoy data provides good estimates of the velocity-depth profiles on the order of $0.1 \mathrm{~km} / \mathrm{s}$. Because the curvature of a deep reflection is affected by the velocity within overlying layers, the presence of velocity inversions and gradients must be accounted for in the model. When downhole logs are not available, low-velocity layers are not readily recognizable. The effect of interbedded low-velocity layers is a

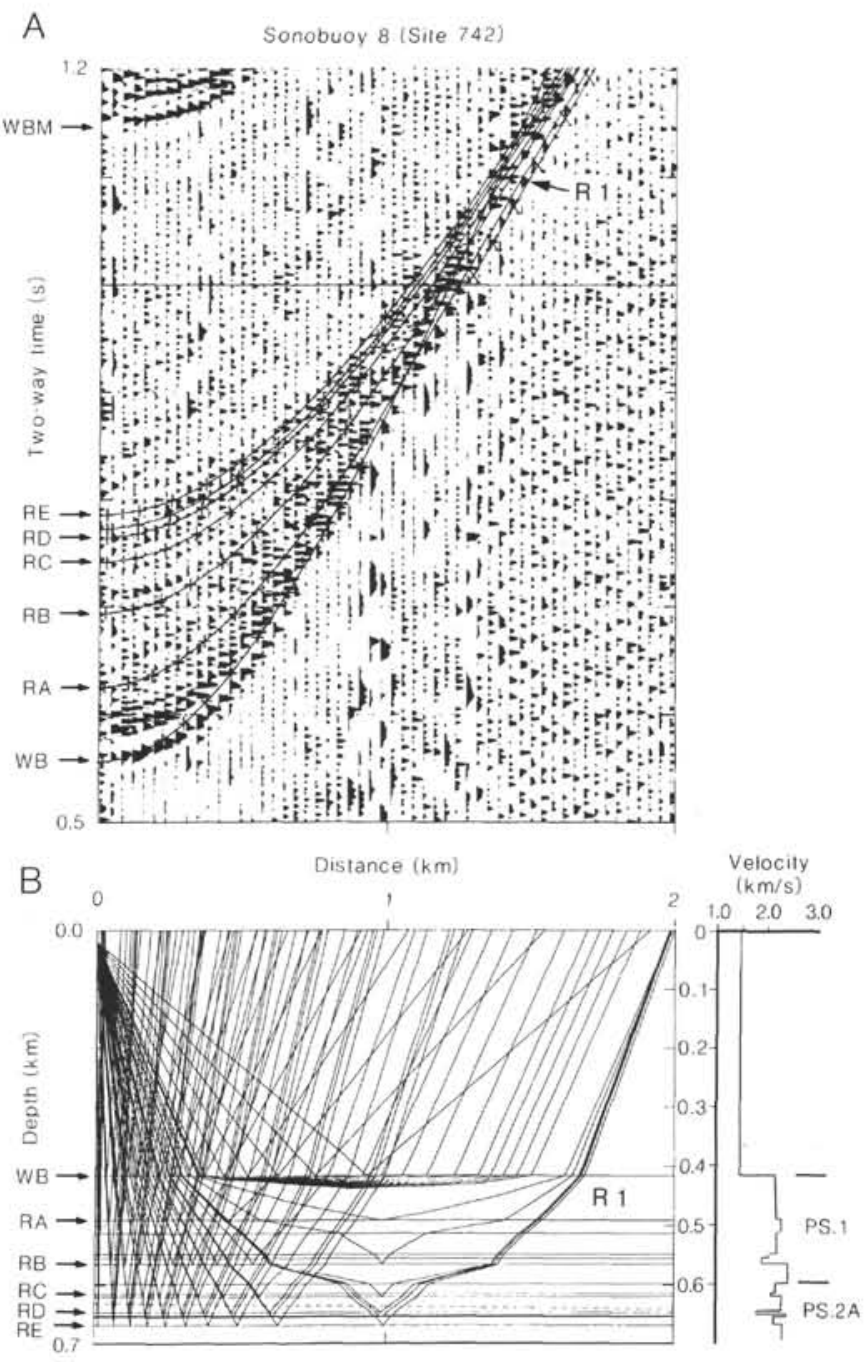

Figure 5. Detailed ray-trace modeling of sonobuoy 8 . WB $=$ water bottom reflection; WBM $=$ water bottom multiple; $\mathrm{R} 1=$ refraction through the near surface; and RA to RE = sub-bottom reflections; RB $=$ reflection from the top of a high-velocity layer at the base of unit PS.1. A. Digitized sonobuoy data and ray-tracing arrival times. B. Velocity-depth model for ray-tracing generated from Site 742 downhole log. Velocity profile shown at right.

slight lowering of the average vertical velocity of the layer in which the low-velocity horizon occurs. However, in this experiment we have shown that where downhole velocity logs are available, calculated traveltime curves can be generated from models using low- and high-velocity layers recognized in the downhole log that match observed reflections in the sonobuoy data if adjustments are made for navigational error and stratigraphic variation along the ship's course. This suggests that modeling with an accuracy on the order of $10 \mathrm{~m}$ is possible if a high-frequency seismic source (dominant frequency greater than $100 \mathrm{~Hz}$ ) is used in place of conventional air guns. Sonobuoy data are useful, even where downhole logging is available, for determining velocities in the near-surface sediment where logging cannot be done, as well as below the bottom of the hole, as discussed in the next section.

\section{REGIONAL VELOCITY STUDY}

The five sonobuoys deployed in Prydz Bay on Leg 119 provide velocities for all major acoustic units of the Prydz Bay 
Table 2. Velocities computed for sonobuoys in Prydz Bay using the ray-tracing method.

\begin{tabular}{|c|c|c|c|c|c|c|c|c|}
\hline Buoy & $\begin{array}{l}\text { Water } \\
\text { depth } \\
\text { (m) }\end{array}$ & $\begin{array}{l}V_{t}-V_{b} \\
h \\
t_{i} \\
\mathrm{R} \#\end{array}$ & $\begin{array}{l}V_{t}-V_{b} \\
h \\
t \\
\mathrm{RH}\end{array}$ & $\begin{array}{l}V_{r}-V_{b} \\
h \\
t_{i} \\
R_{H}\end{array}$ & $\begin{array}{l}V_{r}-V_{b} \\
h \\
t_{i} \\
\mathrm{R} \#\end{array}$ & $\begin{array}{l}V_{t}-V_{b} \\
h \\
t_{i} \\
\mathrm{R} \#\end{array}$ & $\begin{array}{l}V_{r}-V_{b} \\
h \\
t_{i} \\
\mathrm{R} \#\end{array}$ & $\begin{array}{l}V_{t}-V_{b} \\
h \\
t_{i} \\
\mathrm{R} \#\end{array}$ \\
\hline & & Layer 1 & Layer 2 & Layer 3 & Layer 4 & Layer 5 & Layer 6 & Layer 7 \\
\hline 4 & 404 & $\begin{array}{l}2.00-2.01 \\
35 \\
0.035 \\
\mathrm{R} 1\end{array}$ & $\begin{array}{l}1.95-1.95 \\
10 \\
0.113 \\
\text { RB }\end{array}$ & $\begin{array}{l}2.50-2.50 \\
17 \\
0.013\end{array}$ & $\begin{array}{l}2.20-2.20 \\
4 \\
0.004\end{array}$ & $\begin{array}{l}2.50-2.50 \\
16 \\
0.021\end{array}$ & $\begin{array}{l}2.12-2.12 \\
5 \\
0.004\end{array}$ & $\begin{array}{l}2.35-2.35 \\
10 \\
0.009\end{array}$ \\
\hline 5 & 776 & $\begin{array}{l}2.30-2.34 \\
64 \\
0.055 \\
\text { R2 }\end{array}$ & $\begin{array}{l}2.34-2.34 \\
240 \\
0.205 \\
\text { R3 }\end{array}$ & $\begin{array}{l}2.74-2.76 \\
273 \\
0.199 \\
\text { RH }\end{array}$ & $\begin{array}{l}2.85-2.85 \\
217 \\
0.153 \\
\text { R4 }\end{array}$ & $\begin{array}{l}5.7-5.8 \\
230 \\
0.080\end{array}$ & & \\
\hline 6 & 520 & $\begin{array}{l}1.80-1.80 \\
24 \\
0.027\end{array}$ & $\begin{array}{l}2.17-2.22 \\
147 \\
0.133 \\
\text { R5 and RF }\end{array}$ & $\begin{array}{l}2.35-2.40 \\
149 \\
0.126 \\
\text { R6. }\end{array}$ & $\begin{array}{l}2.52-2.52 \\
210 \\
0.167\end{array}$ & $\begin{array}{l}2.65-2.65 \\
175 \\
0.132\end{array}$ & $\begin{array}{l}2.90-2.90 \\
265 \\
0.183\end{array}$ & \\
\hline 7 & 435 & $\begin{array}{l}2.08-2.17 \\
95 \\
0.089 \\
\mathrm{Rl} \text { and } \mathrm{RC}\end{array}$ & $\begin{array}{l}2.21-2.25 \\
100 \\
0.090 \\
\text { RK }\end{array}$ & $\begin{array}{l}2.23-2.23 \\
90 \\
0.081 \\
\text { RL }\end{array}$ & $\begin{array}{l}2.35-2.45 \\
350 \\
0.291 \\
\text { R5 and RF }\end{array}$ & $\begin{array}{l}2.65-2.75 \\
330 \\
0.319\end{array}$ & $\begin{array}{l}3.10-3.10 \\
600 \\
0.387 \\
\text { RM }\end{array}$ & $\begin{array}{l}3.40-3.50 \\
500 \\
0.290 \\
\text { R7 }\end{array}$ \\
\hline 8 & 416 & $\begin{array}{l}2.17-2.19 \\
65 \\
0.069 \\
\mathrm{Rl} \text { and RA }\end{array}$ & $\begin{array}{l}2.28-2.28 \\
22 \\
0.020\end{array}$ & $\begin{array}{l}2.20-2.20 \\
35 \\
0.032\end{array}$ & $\begin{array}{l}2.05-2.05 \\
7 \\
0.007 \\
\text { RB }\end{array}$ & $\begin{array}{l}1.90-1.90 \\
10 \\
0.010\end{array}$ & $\begin{array}{l}2.42-2.42 \\
33 \\
0.027 \\
\text { RC }\end{array}$ & $\begin{array}{l}2.18-2.18 \\
27 \\
0.016\end{array}$ \\
\hline & & Layer 8 & Layer 9 & Layer 10 & Layer 11 & Layer 12 & Layer 13 & Layer 14 \\
\hline 4 & & $\begin{array}{l}2.05-2.05 \\
20 \\
0.019 \\
\text { RC }\end{array}$ & $\begin{array}{l}2.52-2.52 \\
9 \\
0.008\end{array}$ & $\begin{array}{l}2.22-2.22 \\
8 \\
0.007\end{array}$ & $\begin{array}{l}2.07-1.96 \\
43 \\
0.053\end{array}$ & $\begin{array}{l}1.96-1.96 \\
14 \\
0.014\end{array}$ & $\begin{array}{l}2.21-2.21 \\
18 \\
0.016\end{array}$ & $\begin{array}{l}1.91-1.91 \\
4 \\
0.004\end{array}$ \\
\hline 8 & & $\begin{array}{l}2.08-2.08 \\
5 \\
0.005\end{array}$ & $\begin{array}{l}2.30-2.30 \\
21 \\
0.018\end{array}$ & $\begin{array}{l}2.30-2.30 \\
5 \\
0.004\end{array}$ & $\begin{array}{l}1.80-1.80 \\
6 \\
0.007 \\
\text { RD }\end{array}$ & $\begin{array}{l}2.40-2.40 \\
2 \\
0.002\end{array}$ & $\begin{array}{l}2.14-2.14 \\
14 \\
0.012 \\
\text { RE }\end{array}$ & $\begin{array}{l}2.32-2.32 \\
30 \\
0.034 \\
\text { RK } \\
\end{array}$ \\
\hline & & Layer 15 & Layer 16 & Layer 17 & Layer 18 & Layer 19 & Layer 20 & Layer 21 \\
\hline 4 & & $\begin{array}{l}2.43-2.43 \\
27 \\
0.022\end{array}$ & $\begin{array}{l}1.85-1.85 \\
3 \\
0.003\end{array}$ & $\begin{array}{l}2.49-2.49 \\
84 \\
0.068 \\
\text { RG }\end{array}$ & $\begin{array}{l}2.30-2.30 \\
11 \\
0.009\end{array}$ & $\begin{array}{l}2.63-2.63 \\
19 \\
0.014\end{array}$ & $\begin{array}{l}2.63-2.63 \\
139 \\
0.106 \\
\text { RP }\end{array}$ & $\begin{array}{l}2.30-2.30 \\
280 \\
0.243 \\
\text { RQ }\end{array}$ \\
\hline 8 & & $\begin{array}{l}2.41-2.52 \\
262 \\
0.204 \\
\text { R8 and RL }\end{array}$ & $\begin{array}{l}2.70-2.70 \\
510 \\
0.378 \\
\text { RN }\end{array}$ & $\begin{array}{l}3.20-3.20 \\
1110 \\
0.694 \\
\text { RO }\end{array}$ & 0.240 & & & \\
\hline
\end{tabular}

Note: Directly beneath the sonobuoy: $V_{t}$ is the velocity at the top of the layer in $\mathrm{km} / \mathrm{s}, V_{b}$ is the velocity at the bottom of the layer, $h$ is the thickness of the layer in meters, $t_{i}$ is the interval in two-way traveltime for the layer, and R\# is the reference number in the text indicating which reflections and refractions bottom out in the layer.

shelf along the Leg 119 transect (Fig. 2). This section presents the ray-trace modeling results for the three sonobuoys deployed at locations where downhole velocity logs were not obtained. The reflections and refractions from layers beneath the bottoms of Sites 742 and 739 are also modeled.

Inspection of the sonobuoy data indicate that reflections with a zero-offset, vertical, two-way traveltime spacing of $0.02 \mathrm{~s}$ can be resolved. This suggests that a layer thickness of $20 \mathrm{~m}$ could be resolved in the areas where well logging was not done based on an assumption that the minimum velocity will be approximately $2 \mathrm{~km} / \mathrm{s}$. The initial model is constructed based on the shipboard slope-intercept velocities (Table 1) and the seismic-reflection records. The final model published herein is the result of top-down modeling where each layer is added to the bottom of the ray-trace model after the fit of the calculated travel time-distance curves to the sonobuoy data for the overlying layers is within $0.02 \mathrm{~km} / \mathrm{s}$. The water column velocity used for all the models is $1.46 \mathrm{~km} / \mathrm{s}$, based on temperature and salinity measurements made at Prydz Bay drill sites.

\section{Sonobuoy 5 (Site 740)}

Sonobuoy 5 was deployed near Site 740 (Figs. 1 and 2), in which 226 mbsf were penetrated with poor recovery. Here, approximately $15 \mathrm{~m}$ of unit PS.1 unconformably overlies unit PS.4 (Barron, Larsen, et al., 1989) (Fig. 11). Slope-intercept velocity solutions of the sonobuoy data (Table 1) for two refractions (R2 and R3; Fig. 12A) yielded velocities of 2.46 and 3.08 $\mathrm{km} / \mathrm{s}$ respectively. Ray-trace modeling was done for the same refractions, wide-angle reflections, and an additional faint highvelocity refraction visible at distances greater than $2.8 \mathrm{~km}$ and traveltimes greater than $2.0 \mathrm{~s}$ (R4; Fig. 12A).

The velocity-depth model of sonobuoy 5 (Fig. 12B) shows that velocities in the near-surface layer $(2.3 \mathrm{~km} / \mathrm{s})$ are higher than would normally be expected. We do not correlate the sur- 


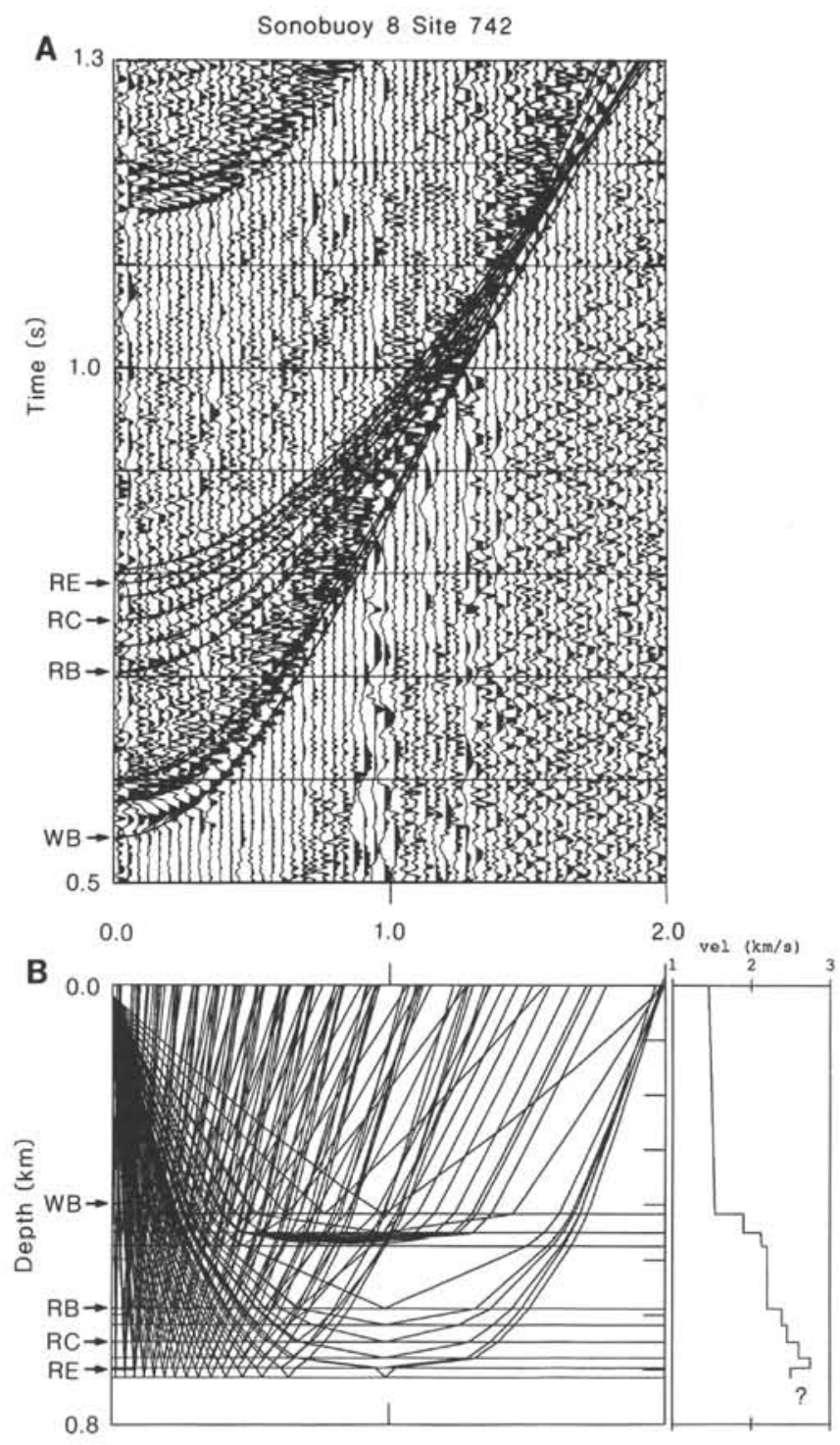

Figure 6. Detailed ray-trace modeling of sonobuoy 8 data using topdown modeling method. $\mathrm{WB}=$ water bottom reflection; $\mathrm{WBM}=$ water bottom multiple; $\mathbf{R} 1$ = refraction through the near surface; and RA to $\mathrm{RE}=$ sub-bottom reflections. A. Digitized sonobuoy data and raytracing arrival times. B. Velocity-depth model for ray-tracing. Velocity profile shown at right.

face refracting layer to refracting layer R1 at the top of unit PS.1, as at the previously discussed sites, because the refraction may occur in the top of unit PS.4. The lithologic samples show that the top 15 mbsf (unit PS.1) at this site is composed of soft diatomaceous ooze (Barron, Larsen, et al., 1989).

Under the thin veneer of unit PS.1 lies $780 \mathrm{~m}$ of rock, divided into four acoustic layers with velocities of approximately 2.3 to $2.8 \mathrm{~km} / \mathrm{s}$ (Table 2), consisting of the non-marine sedimentary rocks of unit PS.4. The faint high-velocity refraction (R3) is from a layer with a velocity of $5.7 \mathrm{~km} / \mathrm{s}$. The top of the layer is marked by a strong reflection at $1.7 \mathrm{~s}$ (Figs. 11 and 12A). Hamilton (1978) shows that velocities for meta-sedimentary rocks range from 3.5 to $6.0 \mathrm{~km} / \mathrm{s}$ with a low vertical-velocity gradient. We believe this underlying layer is metamorphic basement rocks of Precambrian age (unit PS.5) observed onshore (Ravich and Fedorov, 1982), rather than sedimentary strata because of the high velocity and the low vertical gradient.

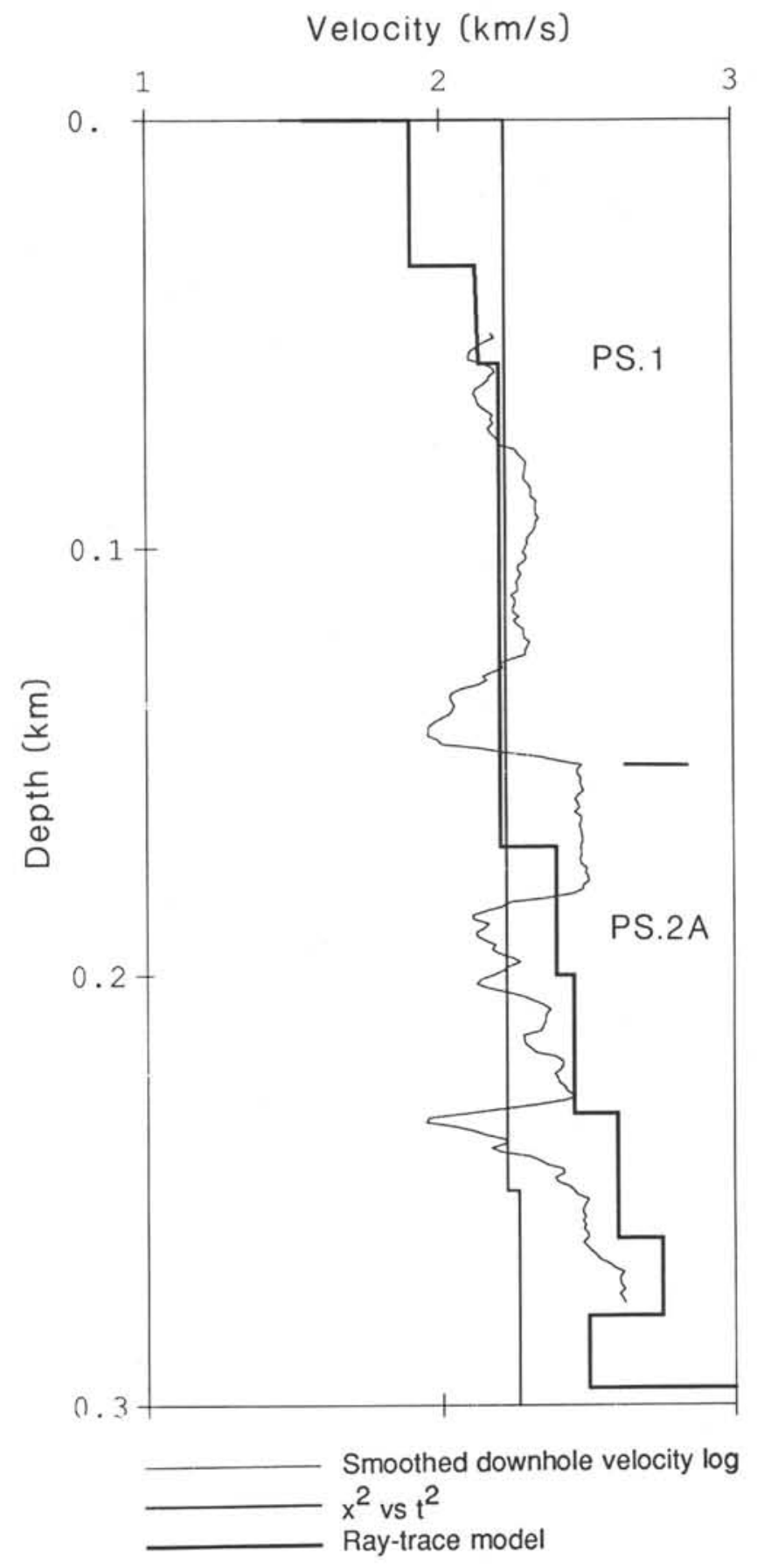

Figure 7. Velocity-depth profiles from Site 742. Water column has been removed from all three profiles for this figure. Acoustic units are shown at right.

\section{Sonobuoy 6 (Site 741)}

Sonobuoy 6 was deployed near Site 741 (Figs. 1 and 2), where drilling penetrated $24 \mathrm{~m}$ of unlithified sediment (unit PS.1) atop unit PS.2B, composed primarily of interlayered sandstone and siltstone with sporadic thin beds of high-velocity (3.2 to $4.8 \mathrm{~km} / \mathrm{s}$ ) cemented sandstone (Barron, Larsen, et al., 1989) (Fig. 13). We have modeled several wide-angle reflections and two refractions (R5 and R6) (Fig. 14A). Several additional lower amplitude reflections with similar curvature in the sonobuoy 
Distance from sonobuoy $4(\mathrm{~km})$

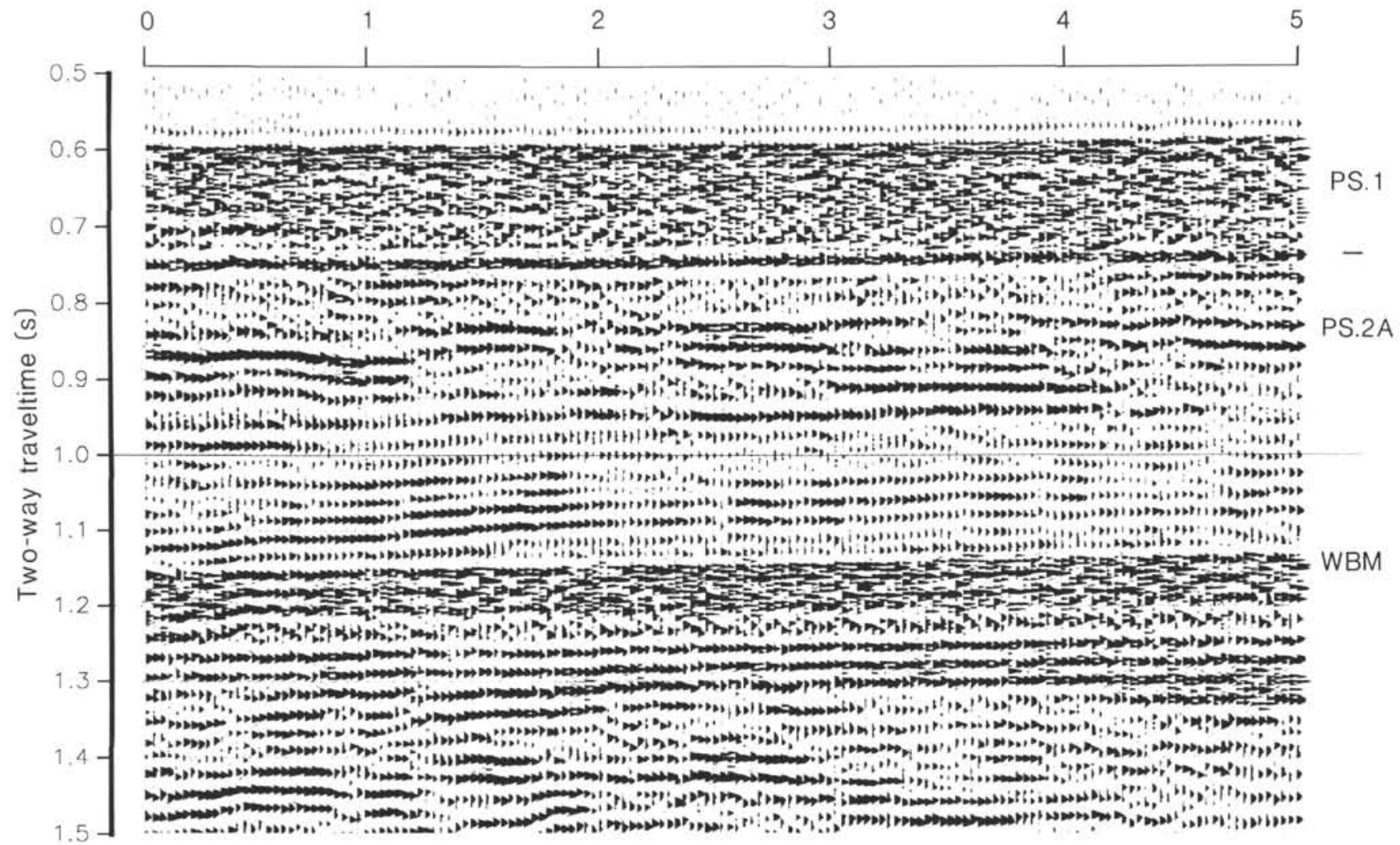

Figure 8. Seismic-reflection profile recorded along strike during shooting of sonobuoy seismic-refraction profile 4. Location of line shown in Barron, Larsen, et al., 1989. Acoustic units PS.1 and PS.2A are shown at right. WBM = water bottom multiple.

data, suggestive of thin layering, are present but were not modeled.

A velocity of $1.8 \mathrm{~km} / \mathrm{s}$ was determined by modeling for the soft diatomaceous ooze and underlying clayey silt of unit PS.1. Unit PS.2B has been subdivided into five layers for the purpose of modeling the major reflections (Fig. 14B). Velocities within unit PS.2B increase fairly uniformly with depth from $2.17 \mathrm{~km} / \mathrm{s}$ near the seafloor to $2.9 \mathrm{~km} / \mathrm{s}$ at $1 \mathrm{~km}$ below the seafloor (Table 2). The velocities for PS.2B are higher than normal for the depths modeled. A better model might have included thin highvelocity layers (cemented sandstone) within a lower velocity matrix that would have produced the same vertically averaged velocity-depth profile. However, without downhole velocity logs we are unable to construct a model with the detail of the previously discussed sites. This model and the other models in this section, based strictly on seismic data, do not include velocity inversions.

\section{Sonobuoy 7}

Sonobuoy 7 was deployed along the geophysical transect, and approximately midway between Sites 741 and 742 (Figs. 1 and 2). Seismic reflection data (Figs. 2 and 15) indicate that unit PS.1 thickens seaward along the transect from Site 741. PS.1 overlies units PS.2A and PS.2B (Cooper et al., this volume). The sonobuoy data show a relatively high-velocity, near-surface refraction (R1) associated with unit PS.1, as with sonobuoys 4 and 8 (Fig. 16A). A strong reflection (RK) is observed within unit PS.2A but no refractions are observed. Additional refractions through layers in unit PS.2B (R5 and R7) are seen. Wideangle reflections RL and RM are off the tops of these refracting layers. The seaward dip of layers within unit PS.2B shown in seismic-reflection data (Fig. 2) is included in the model (Fig. 16B).

The vertically averaged velocity for $\mathrm{R} 1$ at this sonobuoy site is $2.12 \mathrm{~km} / \mathrm{s}$ (Table 2). As at all other sites, this high near-surface velocity suggests overconsolidation possibly due to glacial loading. The high-velocity layer at the base of unit PS.1 that produces reflection RB (Fig. 10) was not modeled; however, a high-amplitude reflection observed at $0.63 \mathrm{~s}$ (zero-distance; Fig. 16A) could be associated with a high-velocity layer. The lack of refractions from layers in unit PS.2A is consistent with the results from the detailed modeling of sonobuoys 4 and 8 which suggests that unit PS.2A is laterally discontinuous. The refraction through the top layer of PS.2B (R5) is consistent with the results of modeling sonobuoy 6 . The additional deeper refraction through PS.2B (R7) is not observed in sonobuoy 6 data but may have been obscured by the decreased signal-to-noise ratio in sonobuoy 6 data. In general, velocities from modeling of sonobuoy 7 data (Fig. 16B) increase fairly uniformly with depth from a higher than normal near surface velocity $(2.1 \mathrm{~km} / \mathrm{s}$, Table 2) to a velocity of $3.4 \mathrm{~km} / \mathrm{s}$ at the bottom of the model $(2.5$ $\mathrm{km}$ ) that is typical of sedimentary rocks at these depths (Hamilton, 1978).

\section{Sonobuoy 8 (Site 742)}

Deeper reflecting layers were added to the velocity-depth model for Site 742 discussed in the previous section (Fig. 5B). Additional wide-angle reflections and one refraction were modeled (Fig. 17A). In general, the velocity-depth model for sonobuoy 8 (Fig. 17B) is similar to those of sonobuoys 6 and 7 . Velocities in the model do not exceed $3.2 \mathrm{~km} / \mathrm{s}$ for depths less than $2.7 \mathrm{~km}$. A refraction through the lower section of unit PS.2A 


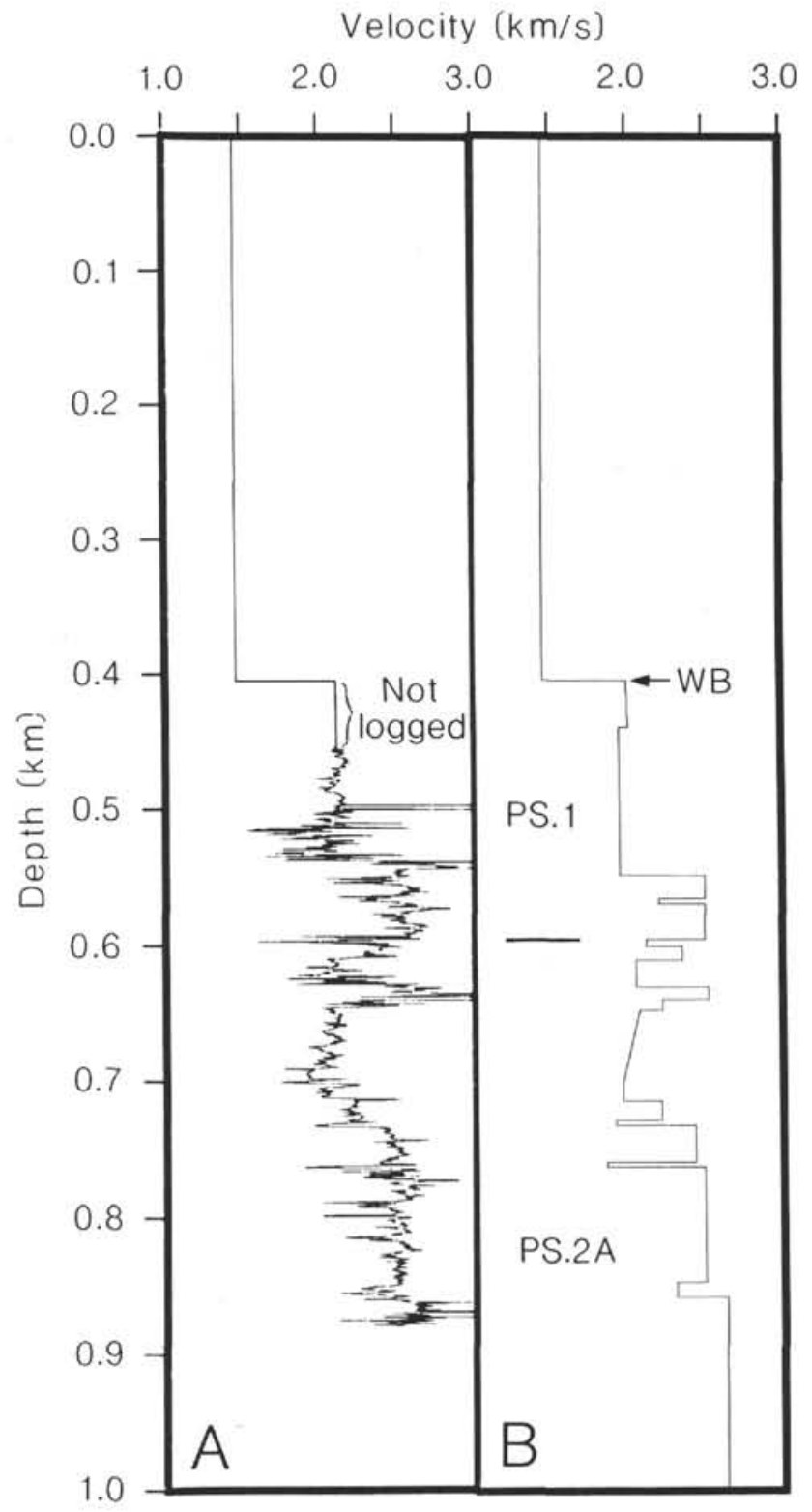

Figure 9. Site 739 velocity-depth profiles. A. Downhole velocity log from Site 739. B. Discrete layer model of the downhole log for ray-trace modeling of sonobuoy 4 . WB $=$ water bottom.

(R8) is observed. No such refraction was observed in sonobuoy 7 data, which suggests that the composition of the unit has changed along the transect between these sites. The deeper refracting layer (R5) observed in the sonobuoy 6 and 7 data within unit PS.2B is not observed at this site. This is also suggestive of some compositional or structural changes in this unit seaward of sonobuoy 7 .

\section{Sonobuoy 4 (Site 739)}

Reflections from two-layer boundaries below the bottom of the Site 739 downhole velocity log were modeled (RP and RO; Fig. 18A). There is no visible refraction that could be correlated with the deeper refracting layer of unit PS.2A (R8) observed in sonobuoy 8 data (Figs. 2 and 17B). The thickness of section within unit PS.2A overlying the refracting layer modeled from sonobuoy 8 data appears to thicken in the seismic reflection data (Cooper et al., this volume) (Fig. 2). This increased thick-

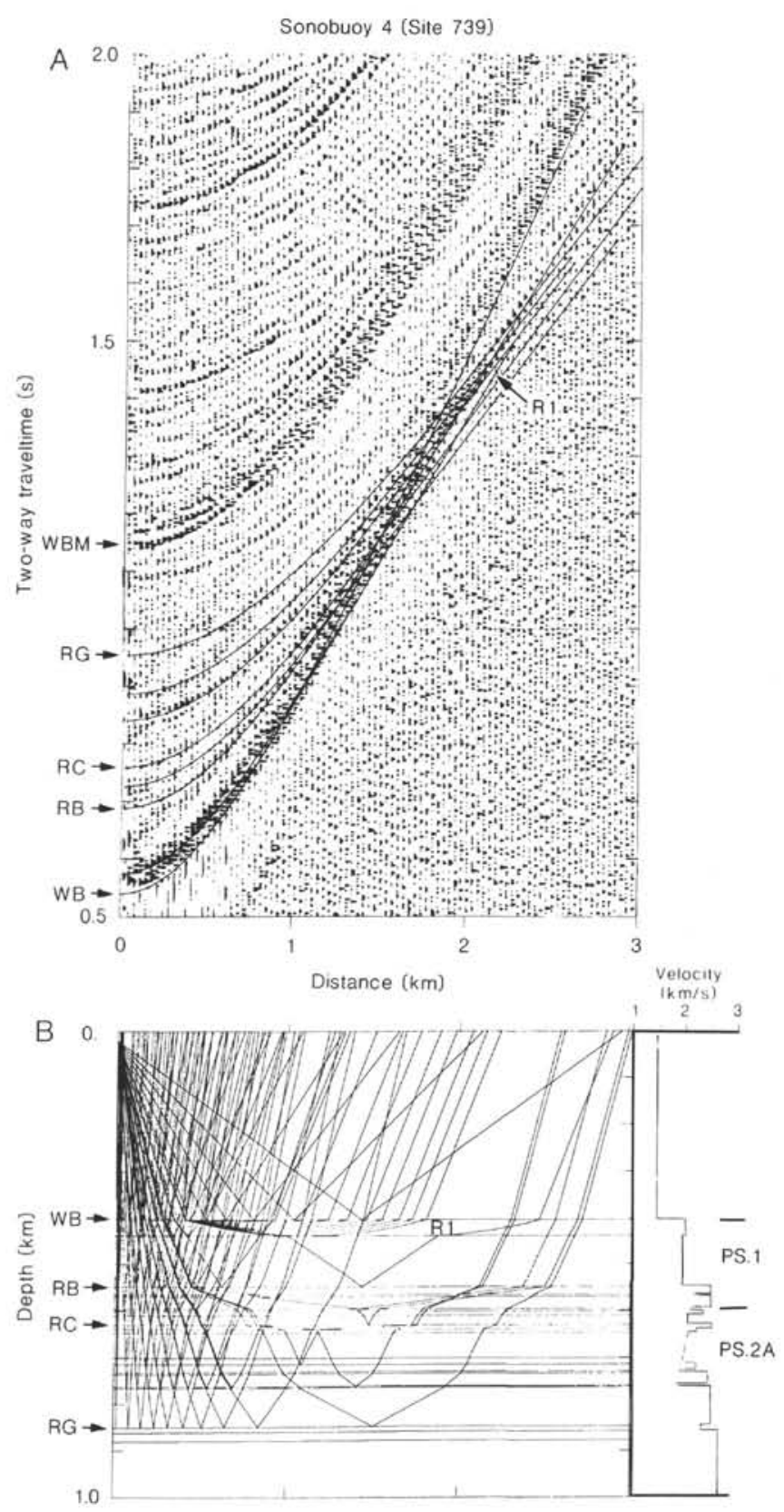

Figure 10. Detailed ray-trace modeling of sonobuoy 4 data. WB = water bottom reflection; WBM = water bottom multiple; $\mathrm{R} 1$ = refraction through the near surface; and RA to RE = sub-bottom reflections; RB $=$ reflection from the top of a high-velocity layer at the base of unit PS.1. A. Digitized sonobuoy data and ray-tracing arrival times. B. Velocity-depth model for ray-tracing generated from Site 739 downhole $\log$. Velocity profile shown at right.

ness of section may be due to greater deposition of slope and shelf deposits or less glacial erosion or a combination of more deposition and less erosion at the edge of the shelf.

\section{SUMMARY AND CONCLUSIONS}

Where downhole velocities are available, time-distance curves can be generated with ray-tracing for models generated from the downhole velocities that match sonobuoy seismic-refraction records at the $0.01-\mathrm{km}$ scale if the navigation is accurate. When the ship's speed and direction vary, corrections must be applied to the data or else accuracy will drop by an order of magnitude. 


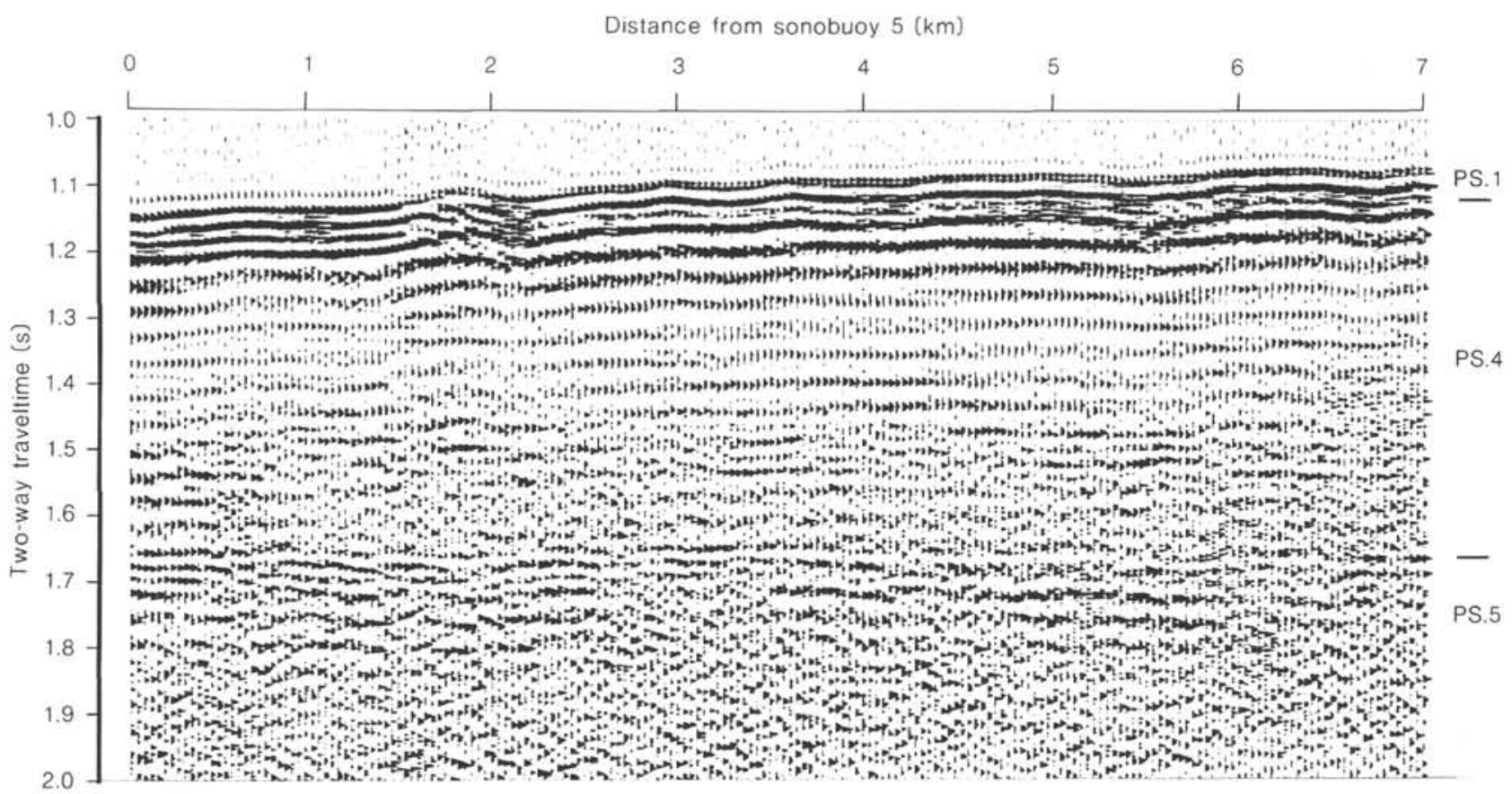

Figure 11. Seismic-reflection profile recorded along strike during shooting of sonobuoy seismic-refraction profile 5. Location shown in Barron, Larsen, et al., 1989. Acoustic units PS.1, PS.4, and PS.5 are shown at right.

Sonobuoys are also useful for determination of velocities in the near surface (i.e., the upper 50 to $100 \mathrm{~m}$ ) where logging cannot be done, and for extending velocity estimates to depths below the bottom of the hole. However, ray-trace models based on sonobuoy data obtained using conventional navigation and air guns cannot typically include velocity inversions or layers thinner than $0.01 \mathrm{~km}$, but will instead have thicker layers with similar vertically averaged velocities.

Based on ray-trace modeling, acoustic units along the Leg 119 transect can be identified in sonobuoy seismic-refraction data by the following characteristics:

Seaward of sonobuoy 7 (Fig. 19), the upper part of unit PS.1 is identified by a $2.0-$ to $2.2-\mathrm{km} / \mathrm{s}$ refraction (R1) through a layer of overcompacted diamictite.

In the lower part of unit PS.1, a seaward thickening and high-velocity layer appears on the outer shelf about 150 to 250 $\mathrm{km}$ from shore (Fig. 19). This layer is characterized by a relatively high-velocity $(2.5 \mathrm{~km} / \mathrm{s})$ reflecting layer (RB). This layer has a uniform velocity (i.e., no vertical gradient) and corresponds to a highly consolidated massive diamictite.

There do not appear to be any consistent characteristics in the vertical-velocity profiles calculated from sonobuoy and downhole velocity logging for unit PS.2A from one site to the next. In general, the velocities for this unit increase with depth from $2.2 \mathrm{~km} / \mathrm{s}$ at approximately at the top of the unit to $2.6 \mathrm{~km} / \mathrm{s}$ at the bottom of the unit. The velocities are higher than commonly found elsewhere at equivalent depths (Hamilton, 1978) and may indicate some erosion of overburden during a glacial period. Two Japanese sonobuoys deployed on the shelf to the west of the Leg 119 transect (J7 and J8; Fig. 1) show approximately 300 m of sediment with a velocity of approximately $1.7 \mathrm{~km} / \mathrm{s}$ at the seafloor, overlying rocks with velocities of 2.3 and $2.9 \mathrm{~km} / \mathrm{s}$ (Mizukoshi et al., 1988). Seismic-reflection data suggest that the near-surface rocks beneath sonobuoys $\mathrm{J} 7$ and $\mathrm{J} 8$ are from unit PS.2A (Cooper et al., this volume) and should have higher velocities than observed.
Unit PS.2B is within about $20 \mathrm{~m}$ of the seafloor over much of the inner shelf area of the Leg 119 transect $(40$ to $110 \mathrm{~km}$; Fig. 19). Significant erosion of overburden or glacial loading is indicated in this area by the high near-surface velocities observed. Unit PS.2B has an approximately $2.2-\mathrm{km} / \mathrm{s}$ refraction (R5) beneath the inner shelf. On the outer shelf, this refraction is not evident, perhaps due to the increasing thickness of overburden seaward of sonobuoy 6 (Fig. 19) which results in greater attenuation of the refracted energy. The velocity in the upper part of unit PS.2B increases to $2.5 \mathrm{~km} / \mathrm{s}$ beneath the outer shelf. The increase may be attributable to additional consolidation resulting from the increased thickness of overburden. A $3.4-\mathrm{km} / \mathrm{s}$ refracting layer (R7) is observed beneath sonobuoy 7 ( $90 \mathrm{~km}$; Fig. 19) from deep within the middle of Prydz Bay ba$\sin$. This refraction, which is within unit PS.2B, is not observed in the sonobuoy data farther seaward, possibly because sonobuoys at Sites 742 and 739 lie seaward of Prydz Bay basin (Cooper et al., this volume).

Unit PS. 4 has a fairly uniform increase in velocity with depth, with velocities ranging from $2.3 \mathrm{~km} / \mathrm{s}$ in the near surface at $1.2 \mathrm{~km}$ to $2.6 \mathrm{~km} / \mathrm{s}$ at a depth of approximately $1.8 \mathrm{~km}$.

Unit PS. 5 has a velocity of $5.7 \mathrm{~km} / \mathrm{s}$. Refractions from this unit are faint, continuous, and straight, indicative of a low vertical gradient. These characteristics are commonly associated with metamorphic or igneous rock.

High velocities $(>2.0 \mathrm{~km} / \mathrm{s})$ are observed in near-surface sediments at all sonobuoy sites along the Leg 119 transect. Velocities in near-surface sedimentary rock exceeding $2.0 \mathrm{~km} / \mathrm{s}$ are indicative of sediments that were buried at depths exceeding 500 $\mathrm{m}$ (Hamilton, 1978). Overconsolidation of near-surface sediments occurs in all acoustic units, suggesting erosion and compaction by ice-loading during the period of formation of unit PS.1, as suggested by Solheim et al. (chapter 9, this volume).

Velocity analysis of sonobuoy refraction data indicates that exclusively sedimentary rock is found in the upper 2 to $3 \mathrm{~km}$ of the Prydz Bay shelf along the Leg 119 transect. Basement rock, 

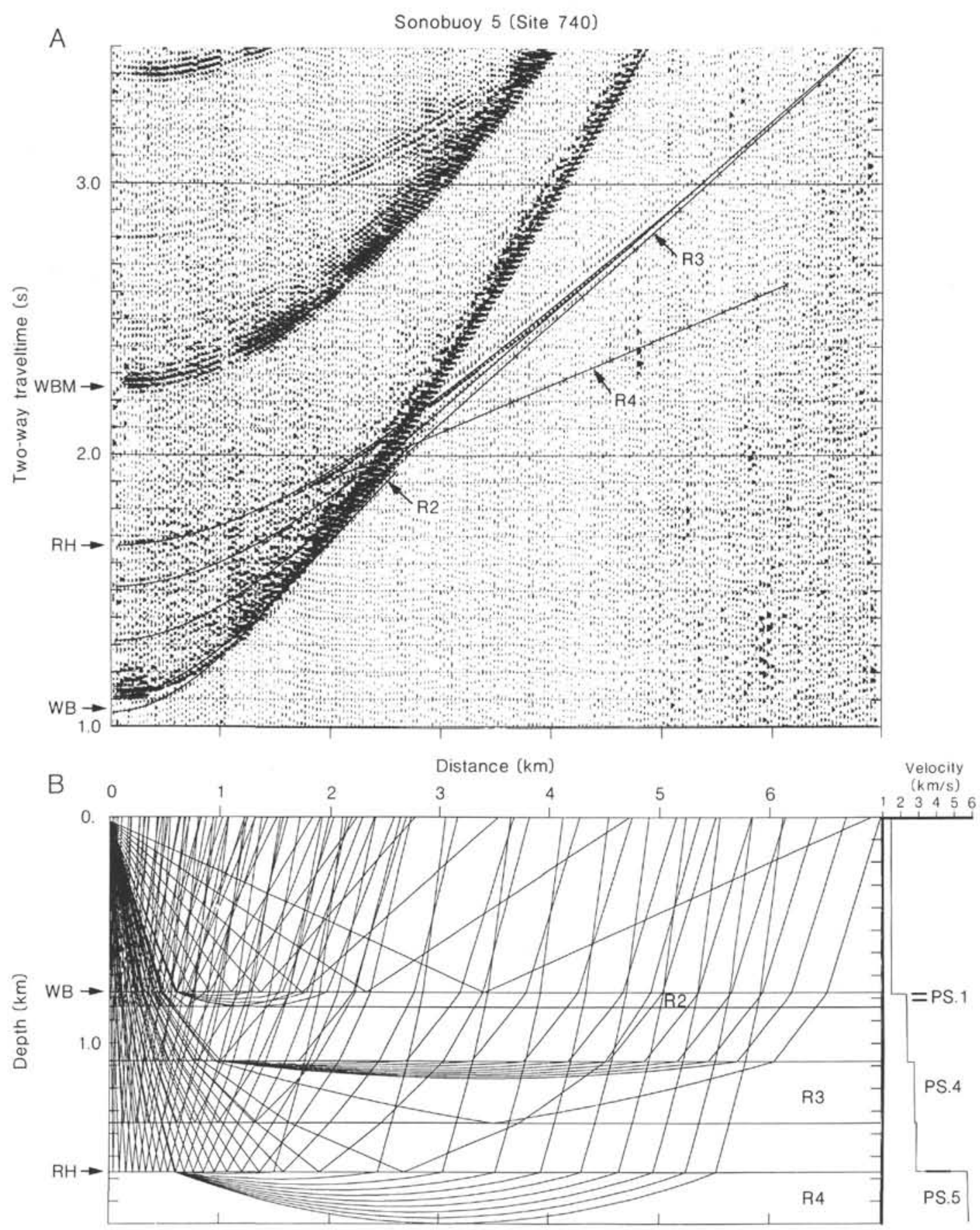

Figure 12. Ray-trace modeling of sonobuoy 5 data. $W B=$ water bottom reflection; $W B M=$ water bottom multiple; R2 to R4 = refractions. A. Digitized sonobuoy data and ray-tracing arrival times. B. Velocity-depth model for ray-tracing. Velocity profile shown at right.

interpreted to be Precambrian metamorphic rocks, is found near the surface only on the landward flank of the Prydz Bay Basin.

\section{ACKNOWLEDGMENTS}

The authors would like to thank Terry Bruns, Holly Ryan, Fred Duennebier, and an anonymous reviewer for their insightful comments. we would also like to thank Brigitta Fulop for assisting with the illustrations.

\section{REFERENCES}

Barron, J., Larsen, B., et al., 1989. Proc. ODP, Init. Repts., 119: College Station, TX (Ocean Drilling Program).
Cerveny, V., Molotkow, I. A., Psencik, I., 1977. Ray Method in Seismology: Praha (Karlova Univ.).

Childs, J. R., and Cooper, A. K., 1975. Collection, reduction and interpretation of marine seismic sonobuoy data. Open-File Rep.-U.S. Geol. Surv., 78-442.

Childs, J. R., and Stagg, H.M.J., 1987. The deep crustal structure of the Wilkes Land continental margin. In Eittreim, S. L., and Hampton, M. A. (Eds.), The Antarctic Continental Margin: Geology and Geophys;cs of Offshore Wilkes Land. Circum-Pacific Council for Energy and Mineral Resources, Earth Sci. Ser., 5A:99-116.

Cooper, A. K., Davey, F. J., and Cochrane, G. R., 1987. Structure of extensionally rifted crust beneath the western Ross Sea and Iselin Bank, Antarctica, from sonobuoy seismic data. In Cooper, A. K., 
and Davey, F. J. (Eds.), The Antarctic Continental Margin: Geology and Geophysics of the Western Ross Sea. Circum-Pacific Council for Energy and Mineral Resources, Earth Sci. Ser., 5B:93-118.

Davey, F. J., Hinz, K., and Schroeder, H., 1983. Sedimentary basins of the Ross Sea, Antarctica. In Oliver, R. L., James, P. R., and Jago, J. B. (Eds.), Antarctic Earth Science: Canberra (Australian Academy of Science), 533-538.

Hamilton, E. L., 1978. Sound velocity-density relations in sea- floor sediments and rocks. J. Acoust. Soc. Am., 63:366-377.

Haugland, K., Kristoffersen, Y., and Velde, A., 1985. Seismic investigations in the Weddell Sea embayment. Tectonophysics, 114:293-313.

McMechan, G. A., and Mooney, W. D., 1980. Asymptotic ray theory and synthetic seismograms for laterally varying structures-theory and application to the Imperial Valley, California. Bull. Seis. Soc. Am., 70:2021-2035.

Mizukoshi, I., Sunouchi, H., Saki, T., Sato, S., and Tanahashi, M., 1988. Preliminary report of geological and geophysical surveys off Amery Ice Shelf, East Antarctica. Mem. Nat. Inst. Polar Res., 43: 48-61.

Stagg, H.M.J., 1985. The structure and origin of Prydz Bay and MacRobertson Shelf, East Antarctica. Tectonophysics, 114:315-340.

Date of initial receipt: 15 September 1989

Date of acceptance: 11 July 1990

Ms 119B-180

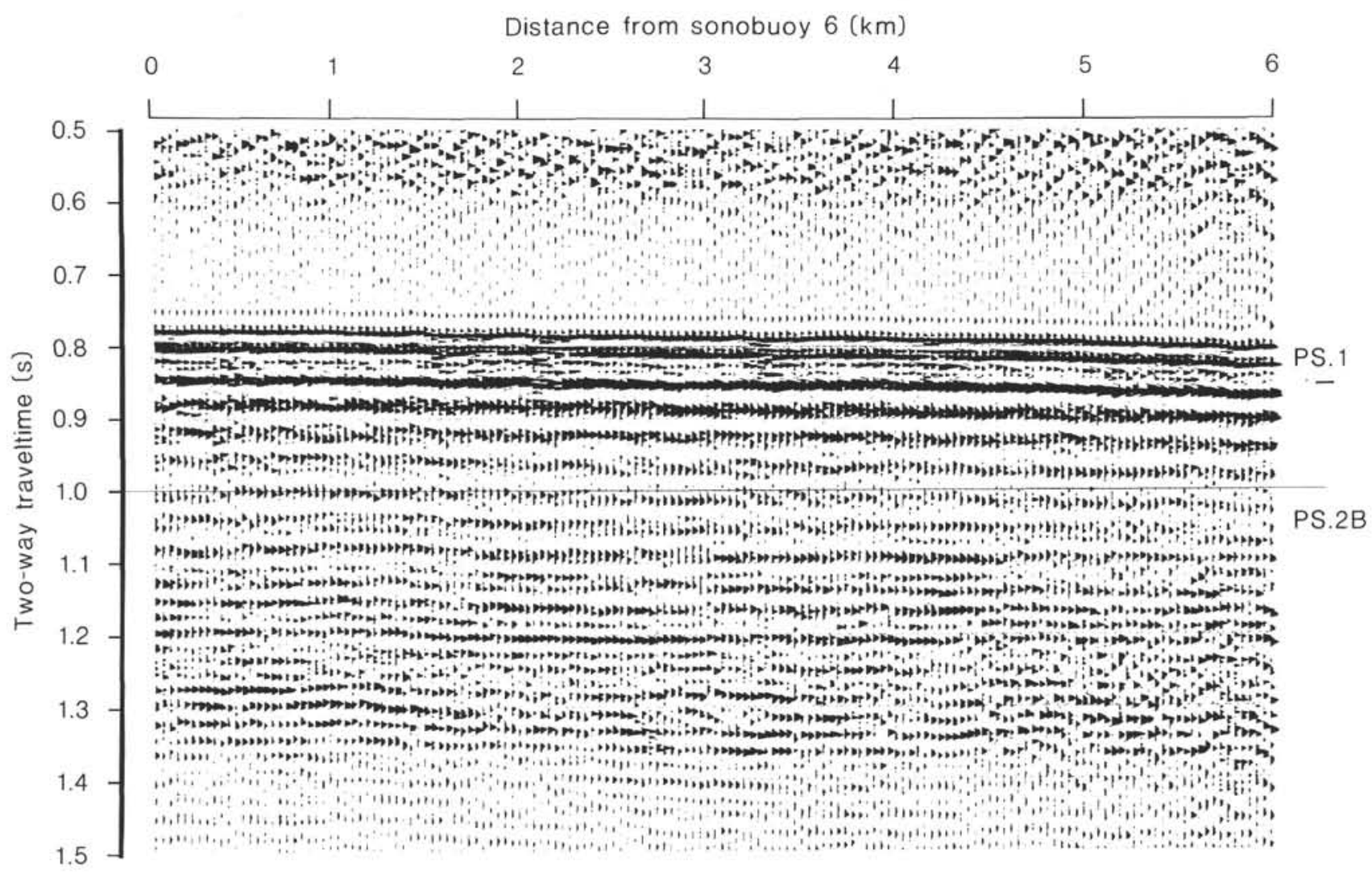

Figure 13. Seismic-reflection profile recorded along strike during shooting of sonobuoy seismic-refraction profile 6 . Location shown in Barron, Larsen, et al., 1989. Acoustic units are shown at right. 

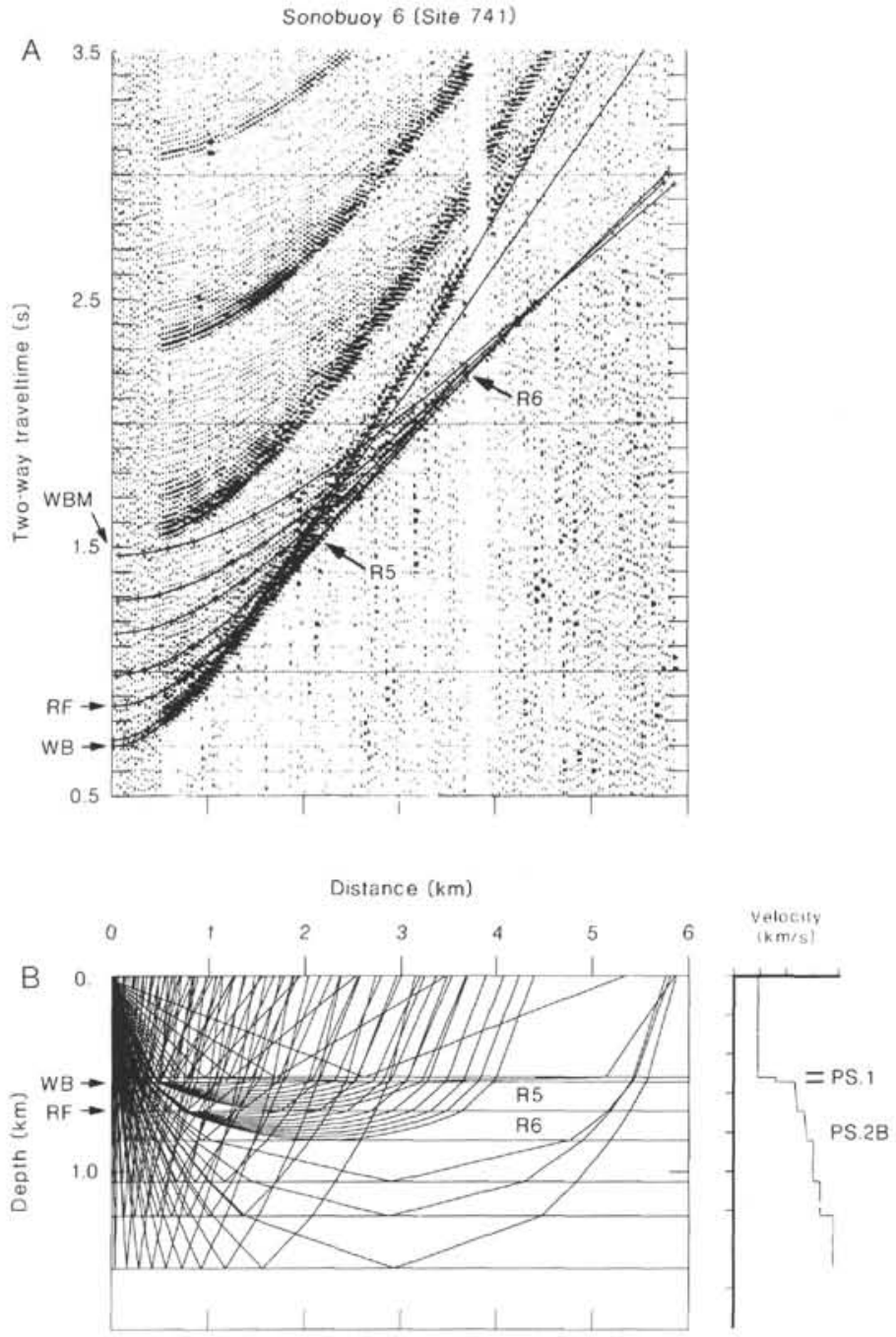

Figure 14. Ray-trace modeling of sonobuoy 6 data. $\mathrm{WB}=$ water bottom reflection; WBM = water bottom multiple; R5 and R6 = refractions. A. Digitized sonobuoy data and ray-tracing arrival times. Data were not recorded for the first 13 shots. B. Velocity-depth model for ray-tracing. 
Distance from sonobuoy $7(\mathrm{~km})$

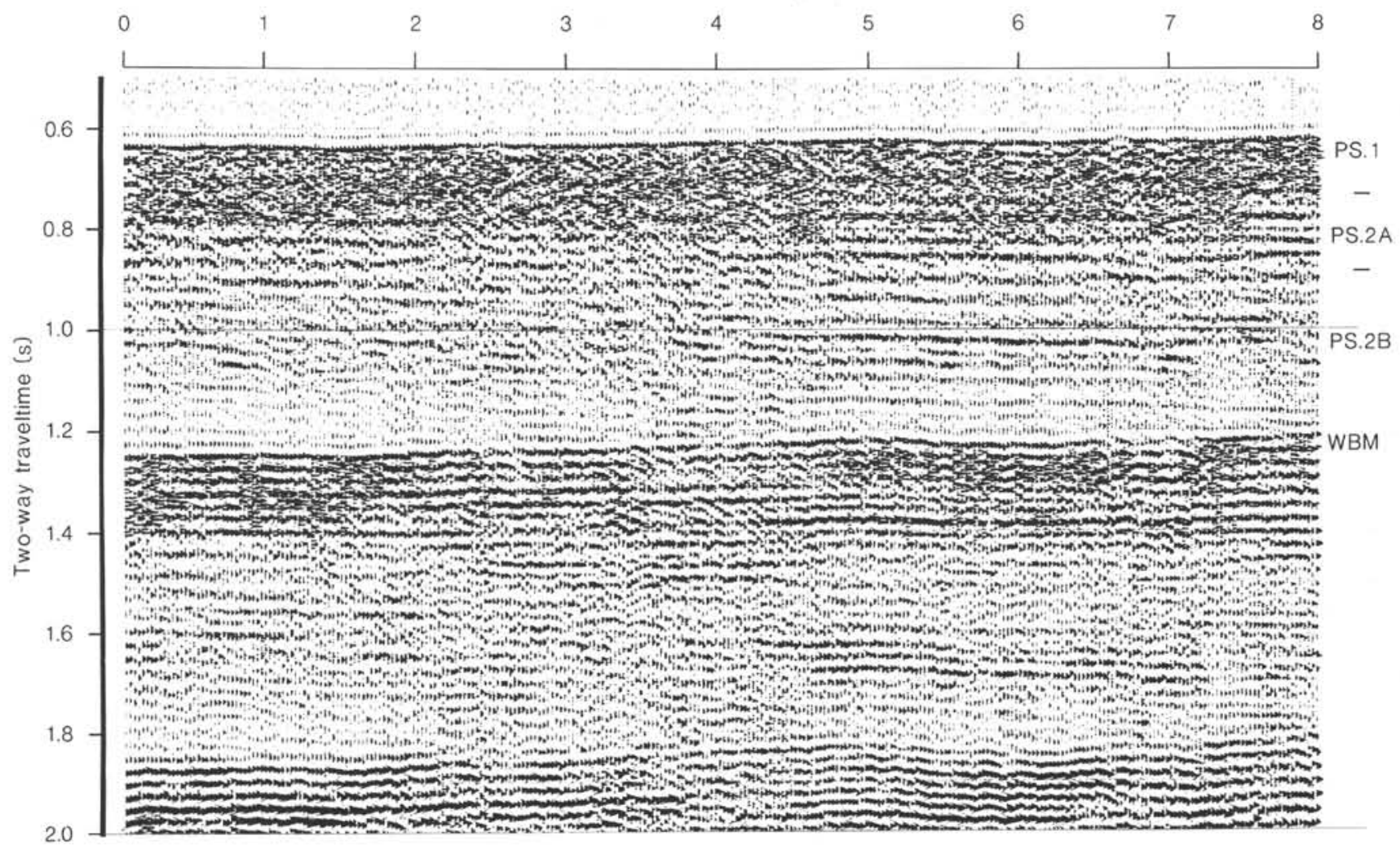

Figure 15. Seismic-reflection profile recorded during shooting of sonobuoy seismic-refraction profile 7. Acoustic units are shown at right. WBM $=$ water bottom multiple. 

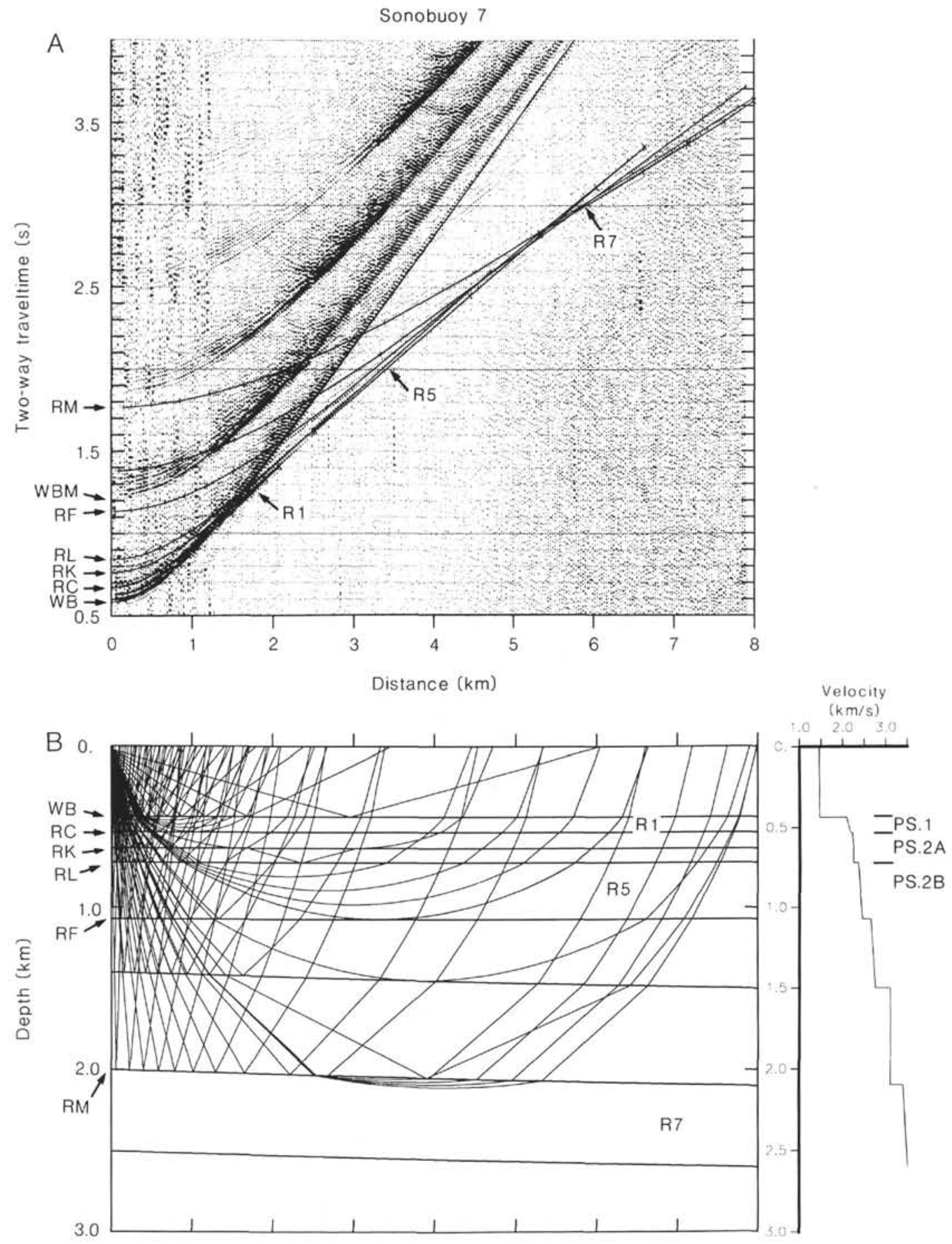

Figure 16. Ray-trace modeling of sonobuoy 7 data. $W B=$ water bottom reflection; WBM = water bottom multiple; RL and RM = reflections; R1, R5, and R7 = refractions. A. Digitized sonobuoy data and ray-tracing arrival times. B. Velocity-depth model for ray-tracing. Velocity profile shown at right. 


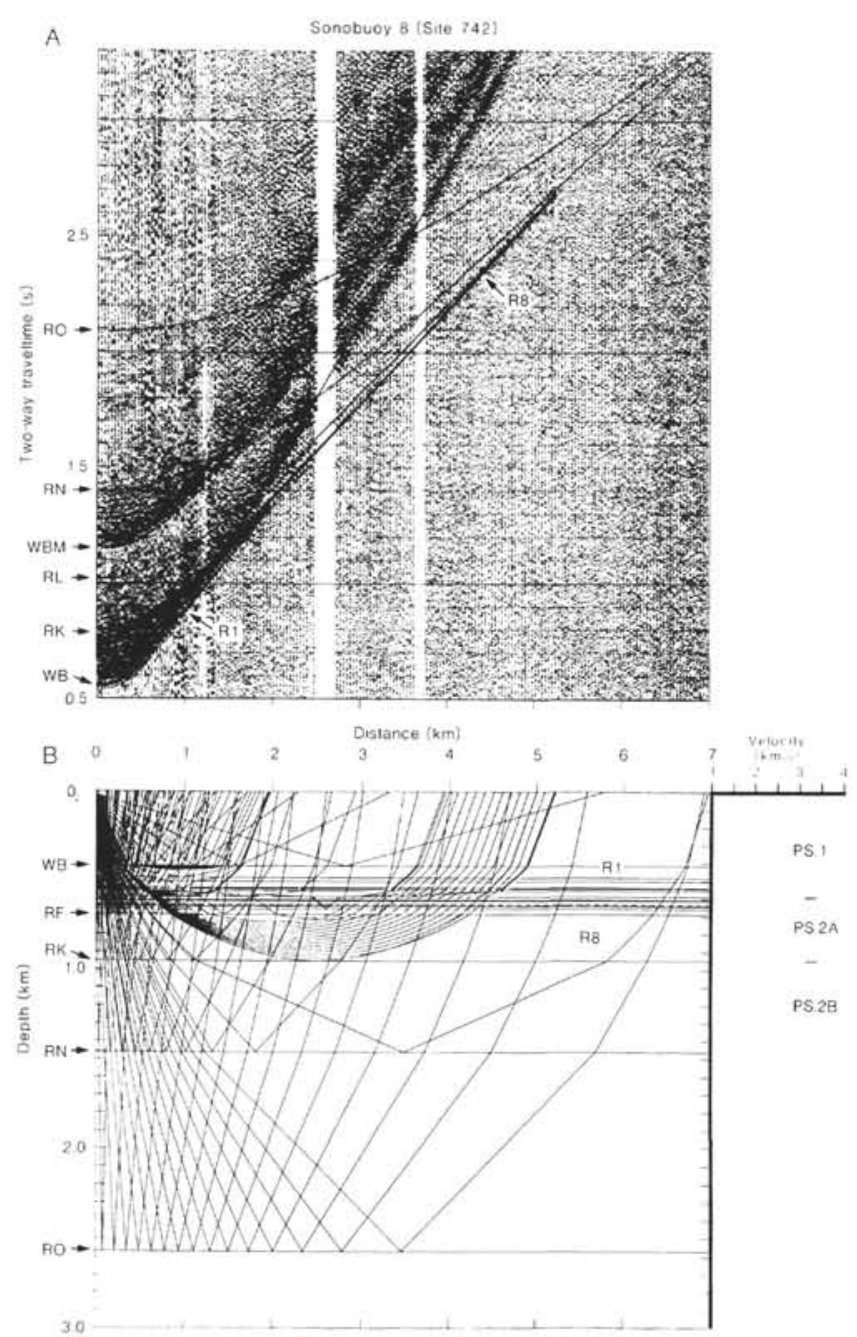

Figure 17. Ray-trace modeling of sonobuoy 8 data including layers below the bottom of the drill hole. WB = water bottom reflection; WBM = water bottom multiple; RF, RL, RN, and RO = reflections; Rl and R8 = refractions. A. Digitized sonobuoy data and ray-tracing arrival times. B. Velocity-depth model for ray-tracing, upper layers are the same as in Figure 5B. Velocity profile shown at right.

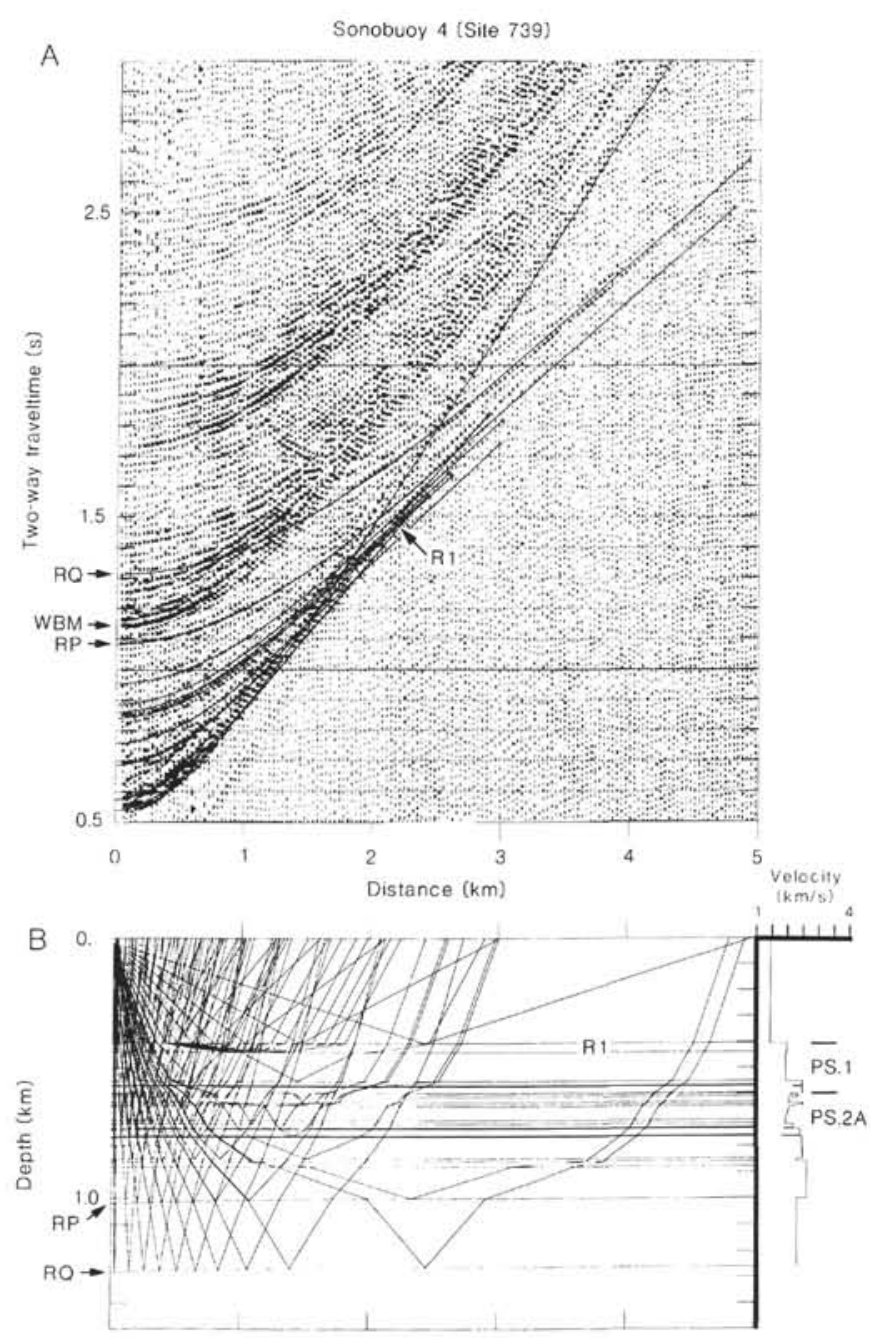

Figure 18. Ray-trace modeling of sonobuoy 4 data including layers below the bottom of the drill hole. WB = water bottom reflection; WBM = water bottom multiple; $\mathrm{RP}$ and $\mathrm{RQ}=$ reflections; $\mathrm{R} 1=$ refraction. A. Digitized sonobuoy data and ray-tracing arrival times. B. Velocitydepth model for ray-tracing, upper layers are the same as in Figure 9B. Velocity profile shown at right. 


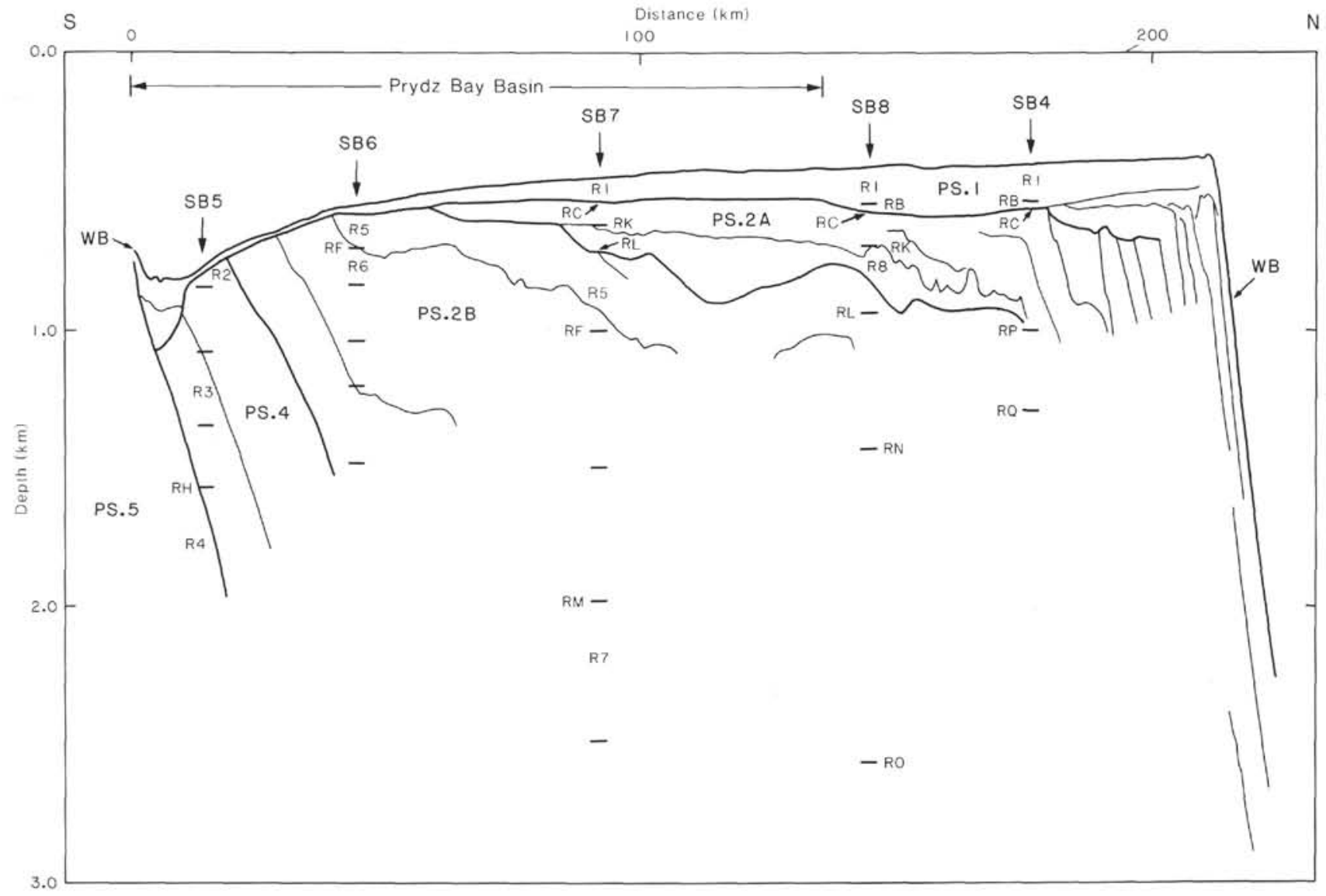

Figure 19. Interpretive line drawing based on seismic reflection data (Fig. 2) converted to depth section using velocities resulting from ray-trace modeling of sonobuoys deployed along the Leg 119 transect. Velocities values used are shown in Table 2. Acoustic unit boundaries are indicated by heavier lines. Significant refracting layers and reflecting boundaries are identified by letters and numbers from the ray-tracing model figures. 